University of Nebraska - Lincoln

DigitalCommons@University of Nebraska - Lincoln

USGS Staff -- Published Research

US Geological Survey

2012

\title{
Development and application of methods used to source prehistoric Southwestern maize: a review
}

Larry Benson

U.S. Geological Survey, great.basin666@gmail.com

Follow this and additional works at: http://digitalcommons.unl.edu/usgsstaffpub

Part of the Agricultural Science Commons, Agriculture Commons, Archaeological Anthropology Commons, Food Science Commons, Genetics and Genomics Commons, Geology Commons, Oceanography and Atmospheric Sciences and Meteorology Commons, Other Earth Sciences Commons, Other Environmental Sciences Commons, and the Plant Breeding and Genetics Commons

Benson, Larry, "Development and application of methods used to source prehistoric Southwestern maize: a review" (2012). USGS Staff -- Published Research. 993.

http:// digitalcommons.unl.edu/usgsstaffpub/993

This Article is brought to you for free and open access by the US Geological Survey at DigitalCommons@University of Nebraska - Lincoln. It has been accepted for inclusion in USGS Staff -- Published Research by an authorized administrator of DigitalCommons@University of Nebraska - Lincoln. 


\title{
Development and application of methods used to source prehistoric Southwestern maize: a review
}

\author{
Larry V. Benson*,1 \\ 602 Pine St, Boulder CO 80302, United States
}

\section{A R T I C L E I N F O}

\section{Article history:}

Received 21 June 2011

Received in revised form

18 August 2011

Accepted 19 August 2011

\section{Keywords:}

Archaeological maize

$\mathrm{Sr}$ isotopes

Chaco Canyon

\begin{abstract}
A B S T R A C T
Archaeological cobs free of mineral contaminants should be used to source the soils in which they were grown. Mineral contaminants often contain much higher concentrations of metals than vegetal materials and can alter a cob's apparent metal and heavy-isotope content. Cleaning a cob via immersion in an acid solution for more than a few minutes will result in the incongruent and sometimes complete leaching of metals, including strontium (Sr), from the cob. When using ${ }^{87} \mathrm{Sr} /{ }^{86} \mathrm{Sr}$ to determine the location of potential agriculture fields, it is best to either integrate several depth-integrated soil samples or to integrate several vegetation samples from individual fields. Biologically labile $\mathrm{Sr}$ in semi-arid Southwestern soils largely originates from eolian source or sources and usually is not derived from underlying bedrock. Existing Sr-isotope data indicate that archaeological cobs from Aztec Ruins came from either the Mesa Verde-McElmo Dome or Totah areas, that Pueblo Bonito and Chetro Ketl cobs, from Chaco Canyon that predate A.D. 1130, probably came from the Rio Chaco corridor, and that cobs from Chaco Canyon, that postdate A.D. 1130, probably came from either the Totah or Zuni areas.
\end{abstract}

Published by Elsevier Ltd.

\section{Introduction}

In this paper I document and criticize the evolution of specific chemical methods used to determine the location of agricultural field systems, which provided maize to Pre-Columbian Native Americans that once occupied Chaco Canyon, New Mexico. The chemical methods have been outlined in several previously published papers (Benson, 2010; Benson et al., 2003, 2006b, 2008, 2009, 2010). In essence, I discuss what worked, what didn't work, and what should be done in future studies that apply heavy isotopes, such as ${ }^{87} \mathrm{Sr} /{ }^{86} \mathrm{Sr}$, to the sourcing of organic archaeological materials. Lastly, I indicate the possible source areas of archaeological maize cobs found in Chaco Canyon and Aztec Ruins, New Mexico. Movement of basic materials including foodstuffs over substantial distances argues for a certain level of socio-economic organization and the presence of regional rather than just local control. Knowledge of where archaeological cobs found in Chaco Canyon were grown provides some insight as to the nature of socio-

\footnotetext{
* Tel.: +13035413005 .

E-mail address: lbenson@usgs.gov.

1 Adjunct, Curator of Anthropology, Museum of Natural History, Affiliate of the Institute of Arctic and Alpine Research, University of Colorado; Emeritus, U.S. Geological Survey.
}

economic organization before and after the near abandonment of Chaco during the middle-12th-century drought.

\section{Archaeological background}

${ }^{2}$ Chaco Canyon, New Mexico, now included within the Chaco Culture National Historical Park in the central San Juan Basin (Fig. 1), was once the political center of a vast region populated by Pre-Columbian Southwestern Native Americans. Between A.D. 860 and 1130, 12 great houses were constructed within Chaco Canyon (Fig. 2). Pueblo Bonito was one of three great houses whose initial construction occurred between A.D. 860 and A.D. 900 and whose final construction phase terminated at A.D. 1129 (Fig. 3) (Windes, 2003). Between A.D. 1040 and A.D. 1130, Chaco Canyon flourished; a massive construction episode occurred at both new and old great houses, and a great deal of labor was invested in the construction and formalization of ritual-related landscape features such as great kivas, mounds, and engineered roads (Sebastian, 2006).

\footnotetext{
${ }^{2}$ Given that the author is summarizing information from six of his previously published papers, he has taken the liberty of "lifting" methods sections from those papers and inserting them without notable change in this review.
} 


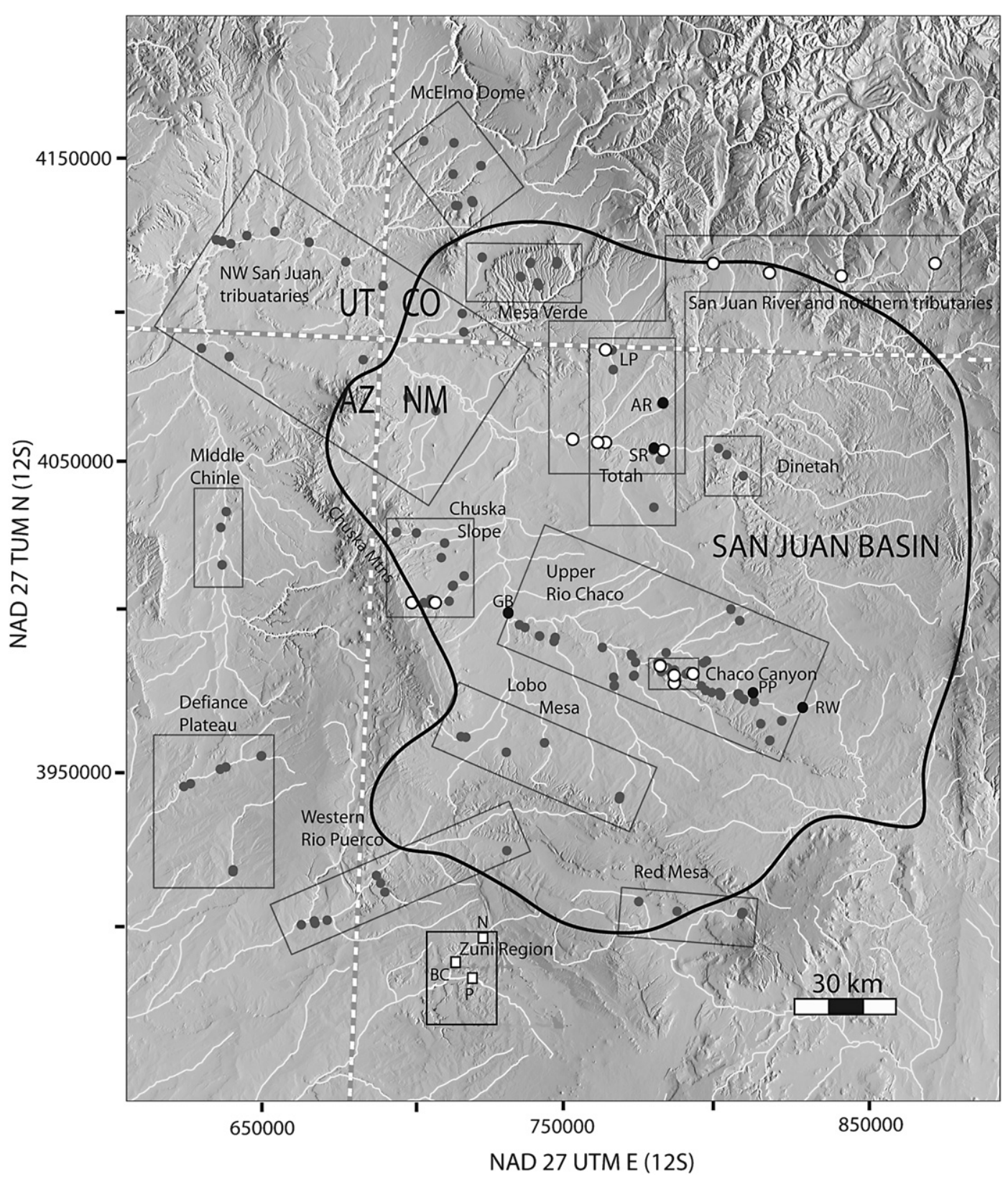

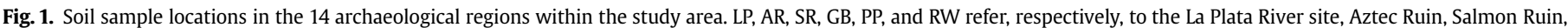

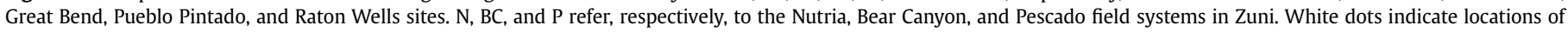

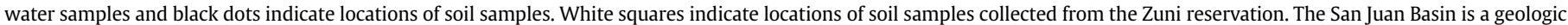
structural basin.

Over 200 smaller great houses were constructed within an $88,000 \mathrm{~km}^{2}$ area surrounding Chaco Canyon (Fig. 4). Most of these satellite great houses, as well as those in Chaco Canyon, were abandoned shortly after A.D. 1130 during the start of a 30-year-long megadrought (Fig. 5) (see, e.g., Dean and van West, 2002; Benson et al., 2007; Benson and Berry, 2009; and Berry and Benson, 2010 for discussions of megadroughts that occurred in the Southwest between A.D. 900 and 1400). The ritual/political relation of these outlier great houses to those in the Canyon remains a subject of conjecture; for example, to quote Judge and Cordell, 2006 "Did the Chacoan polity arise from chiefly power gained by, or based on, the accumulation of wealth, tending toward more coercive leadership, or did it arise from priestly authority acquired through, or based on, the effectiveness of esoteric ritual, tending toward more cooperative leadership?" We will probably never know the exact nature of the ties/forces which held the overall Chacoan region together because written records do not exist and because the information embedded in archaeological objects and structures is severely limited in terms of content.

Judge (1979) suggested a cultural model in which the Chacoan elite governed subsistence throughout the study area, initially suggesting that Chaco functioned as a redistribution center for maize. Judge (1989), however, later modified his redistribution model. In the modified model, formal pilgrimages developed during the Classic Bonito phase (A.D. 1020-1100), during which time goods, including maize, were transported to Chaco from outlying villages and consumed in ritual feasts presumably hosted by Chacoan elites. Incorporated within Judge's (1989) model is the concept that Chaco was essentially a "vacant city" and that the multi-roomed great houses were constructed largely to 


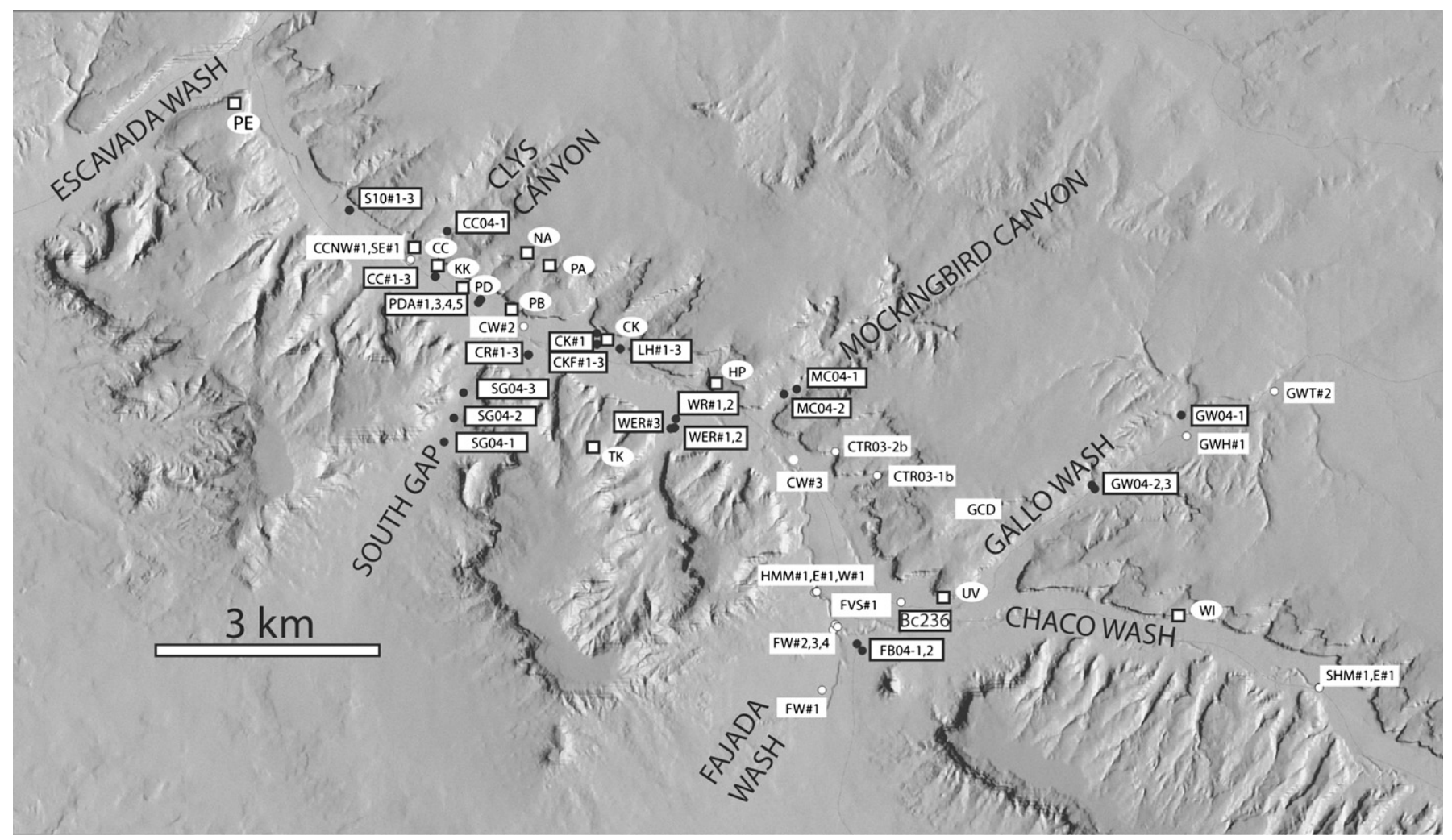

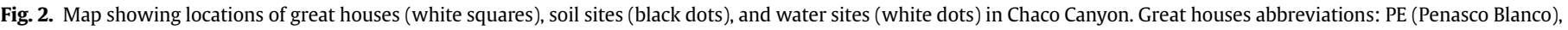

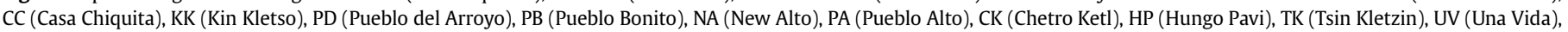

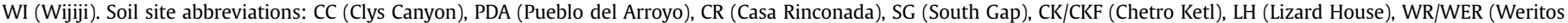

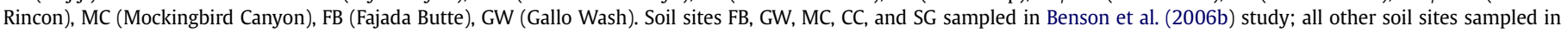

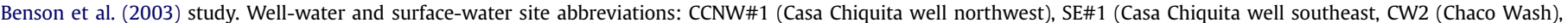

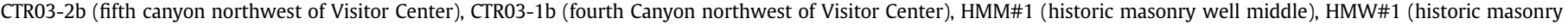

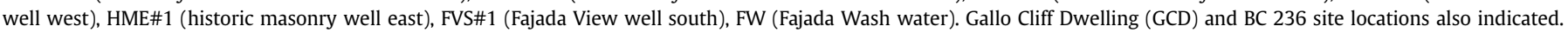

accommodate the influx of people from outside Chaco who participated in the formal pilgrimages. Judge's models imply that most of the maize consumed within Chaco was grown outside Chaco and that the full-time residential population of Chaco was relatively small. Pueblo Bonito, for example, had upwards of 800 rooms, yet its peak occupancy never exceeded 100 individuals (Bernardini, 1999; Windes, 1984).

There are several risk factors associated with dryland maize production within the study area chief among which is the highly variable convective activity (thunderstorms) associated with the summer monsoon. This leads to great spatial variability in the amount (if any) of summer precipitation received at any particular site (Adams and Comrie, 1997). One way prehistoric Southwestern Native Americans may have responded to the spatial variability of summer precipitation was to spread over the landscape in such a way that at least some groups would receive adequate summer precipitation for the cultivation of maize during a "normal" year (yr). In fact, one of the principal methods in locating Chacoan community centers in the San Juan Basin (Marshall et al., 1979) involved the location of small "green" areas in the Basin, using false-image Landsat photos (John Stein, personal communication, 2009). The spatial distribution of great houses and their attendant villages prior to 1130 A.D. (see Fig. 4) supports the existence of such a strategy.

When compared to other archaeological regions within the study area, the agricultural productivity of Chaco Canyon is poor; i.e., Chaco tends to be excessively dry and cold and its soils are too organic-N poor to support abundant maize production (Benson, 2011b). The conclusions in Benson (2011b) are based on modern climate and soil data sets and may be argued to be unrepresentative of prehistoric conditions. In fact, Chaco's precipitation, during the past $60 \mathrm{yr}$ has averaged $22.4 \mathrm{~cm} / \mathrm{yr}$ (median $=21.7 \mathrm{~cm} / \mathrm{yr}$ ) (Table 1 in Benson, 2011b), whereas the average tree-ring-based reconstructed precipitation for the previous $1290 \mathrm{yrs}$ is $22.6 \mathrm{~cm} /$ yr (median $=22.7 \mathrm{~cm} / \mathrm{yr}$ ) (Fig. 11c in Benson et al., 2007, in which Chaco precipitation should have been labeled inches not $\mathrm{cm}$ ). Although prehistoric temperature records for Chaco Canyon do not exist, we would expect that temperatures and, hence, growing season length would, on average, have increased during the historical period due to global and, in particular, Southwestern climate warming. In addition, Chaco Canyon soils have had hundreds of years to recover from the prehistoric production of maize. Thus modern climate and soil data sets should be generally representative of prehistoric environments. As Benson (2011b) has shown, Chaco Canyon historically has received, on average, $22.4 \mathrm{~cm}$ of annual precipitation and $10.5 \mathrm{~cm}$ of summer (June, July, August, September) precipitation, whereas $30 \mathrm{~cm} / \mathrm{yr}$ and $15 \mathrm{~cm} /$ summer are considered the lower limits for modern dryland maize production in the Northern Hemisphere (Shaw, 1988). For Chaco Canyon, a very few annual and summer rains exceed the minimum precipitation requirements during the historical period (Table 1 in Benson, 2011b), indicating the low probability of raising a productive maize crop. Tree-ring-based reconstructions of prehistoric summer precipitation are nonexistent; however, only $2.2 \%$ of the time between A.D. 810 and A.D. 1950 did reconstructed annual precipitation exceed $30 \mathrm{~cm}$. Not only is precipitation a problem for Chaco Canyon, its floodplain soils are saline (Fig. 17B in Benson, 2011b) and its soil pH values are well above optimal values, 


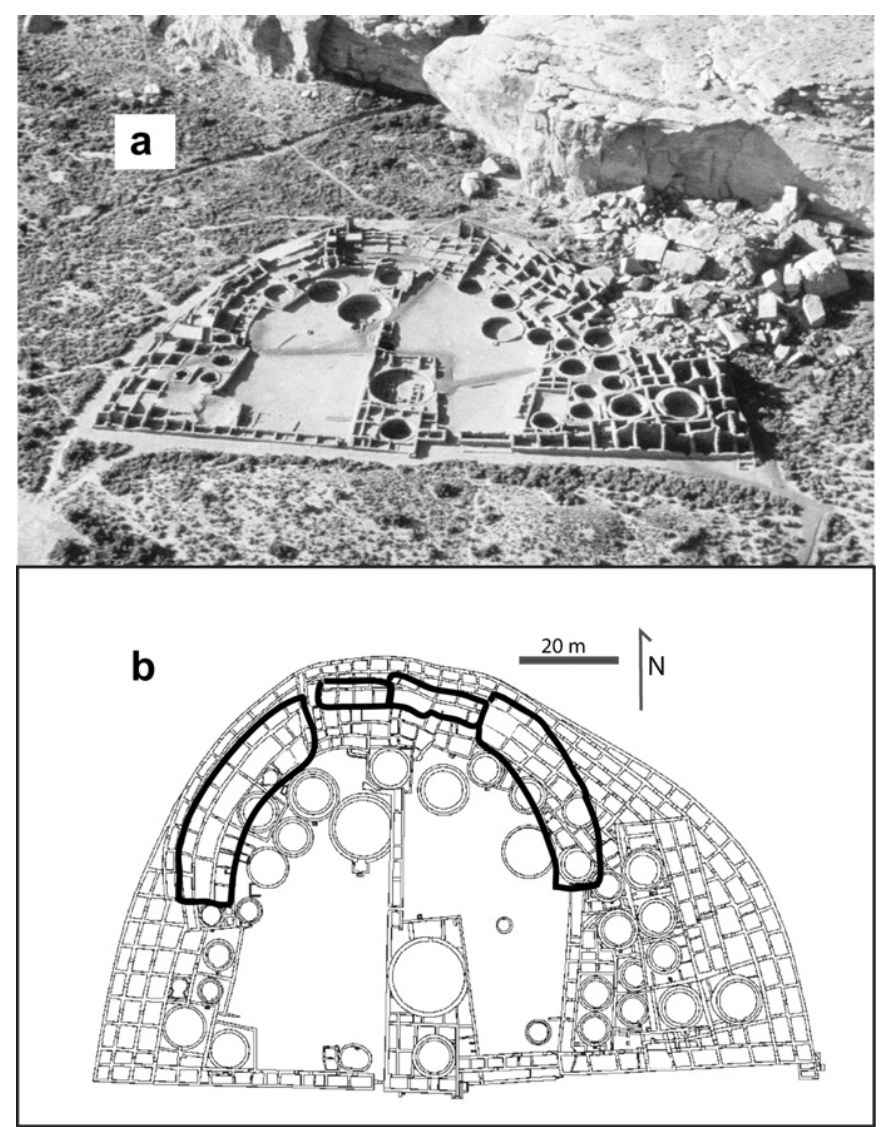

Fig. 3. a, Photo of Pueblo Bonito great house and b, plan view of its structure showing room blocks and kivas. Arc of rooms outlined in black were constructed between A.D. 860 and the A.D. 900s (Windes, 2003).

which limits $\mathrm{P}$ availability and organic-N mineralization rates. In addition, historically about half of the growing seasons at Chaco did not exceed 120 freeze-free days, and one-third of the growing seasons did not exceed 1000 growing degree days (Benson et al., 2011b), which indicates that solar radiation also limits maize

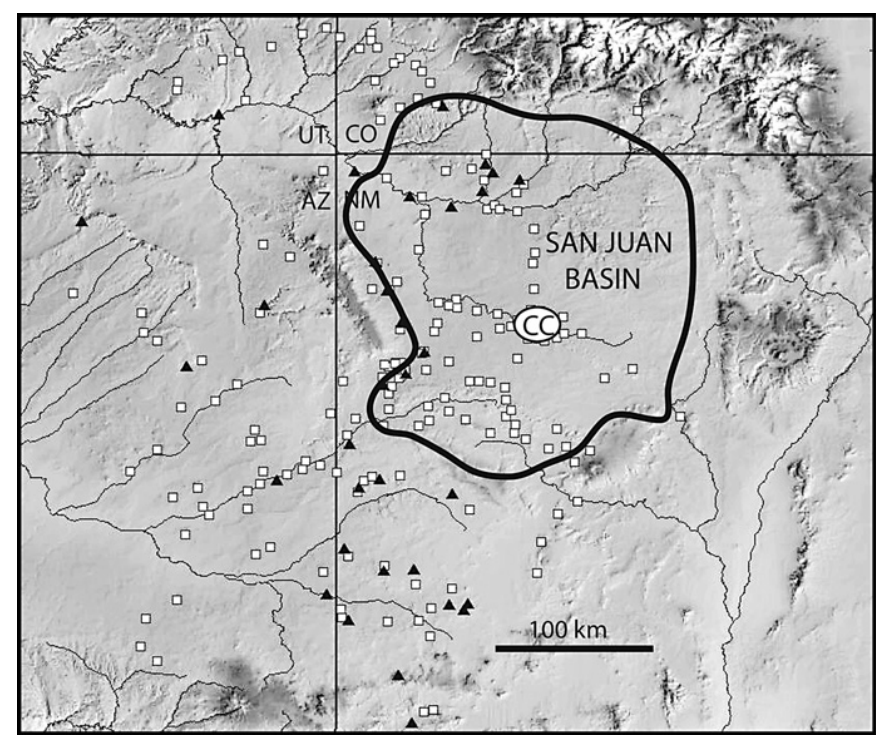

Fig. 4. Locations of "outlier" great houses that surround the Chaco Canyon political center (Kantner, 2003 and references therein). Great houses abandoned by $\sim$ A.D. 1150 shown as white squares. "CC" indicates location of Chaco Canyon.
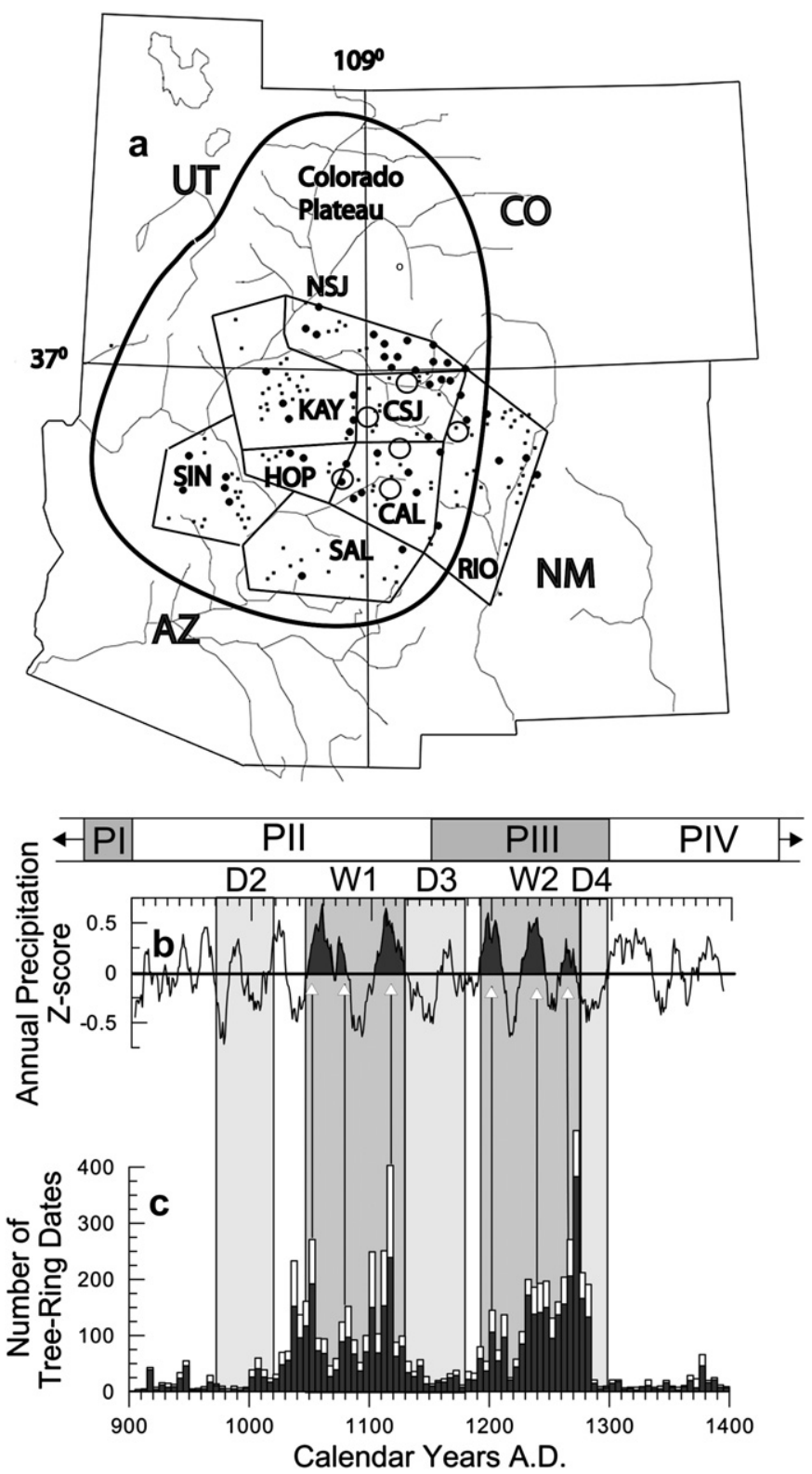

Fig. 5. a, Map showing location of cutting-date sites and archaeological regions in and bordering the study area. KAY = Kayenta region, NES = northeastern San Juan Basin, $\mathrm{CSJ}=$ central San Juan Basin, $\mathrm{SIN}=$ Sinagua region, $\mathrm{HOP}=$ Hopi region, $\mathrm{CAL}=$ CibolaAcoma-Laguna region, RIO = Rio Grande region, $\mathrm{SAL}=$ Salt River region. Large open circles indicate locations of tree-ring data sets; medium black circles indicate cuttingdate site clusters; small black circles indicate single cutting-date sites. Heavy black line outlines the Colorado Plateau. b, Mean of six normalized tree-ring precipitation records for the period A.D. 900-1400 from sites within and at the periphery of the San Juan Basin compared with c, the distribution of tree-ring cutting dates in the study area. Black values indicate "death dates" and white values indicate "v" dates that are a few years younger than the actual death date. Three megadroughts (D2-D4) have been colored light gray; two extended wet periods (W1-W2) have been colored dark gray. P stands for Pueblo period. Vertical arrows point to times of maximum wetness that correlate with maximum cutting numbers.

productivity at Chaco. While none of these arguments prove that maize could not have been grown in Chaco Canyon in times past, tree-ring-based values of prehistoric annual precipitation and the general unreliability of summer monsoon rains suggest that Chaco was a very risky place to grow abundant maize. In terms of the early historic period, the words of Marietta Wetherill, regarding the growth of maize in the Canyon, should be remembered "In the last 
sixteen years, there have been only two good crops" (Huntington, 1914).

These facts support Judge's $(1979,1989)$ arguments that maize was imported to feed those attending pilgrimage fairs, which leads us to one of the topics discussed in this review; i.e., where was the maize grown that was consumed by those that resided in or visited Chaco Canyon?

One area where maize may have been grown is the Chuska slope, which is located in the far western part of the "Chaco Corridor" as redefined by Benson (2011a). To avoid confusion between Doyel et al's (1984) usage of the term "Chaco Halo" and Benson's (2011a) adoption of the same term for a different geographic area, I will use the term "Rio Chaco Corridor" to redefine the region along the Rio Chaco that extends from the Chuska Mountains on the west to Raton Wells on the east. This region encompasses those great houses and villages from the Great Bend of the Rio Chaco on the west $120 \mathrm{~km}$ to Pueblo Pintado on the east as well as those villages and great houses found on the Chuska Slope. In Fig. 1, the Chuska Slope and Upper Rio Chaco soil sampling areas, as well as the land between the two areas, comprise most of the Chaco Corridor. Many of the great houses at the base of the Chuskas, including Newcomb, Skunk Springs, Standing Rock, and Muddy Water were contemporary with Chaco Canyon great houses (Fowler and Stein, 1992; Marshall et al., 1979).

The Chaco Halo, as defined by Doyel et al. (1984), encircled settlements adjacent to Chaco Canyon that were thought to have served as agricultural production centers. The Chaco Halo is an ellipse centered on the Chetro Ketl great house. The 25-km longaxis of the ellipse parallels the Canyon; the short axis of the ellipse is $\sim 12 \mathrm{~km}$ in length.

I suggest that the agricultural production necessary for the subsistence of those living in Chaco Canyon and as well as those coming to the Canyon to feast was supplied by population centers that lay along the Upper Rio Chaco Corridor, especially that part of the corridor that lies between the confluence of the Rio Chaco and Escavada Wash on the east and the base of the Chuska Mountains on the west.

A variety of materials were transported from the Chuskas to Chaco (Fig. 1). Several great houses exist along that corridor, including Great Bend, Sanostee, Escalon, Willow Canyon, Lake Valley, and Casa del Rio, which may have provided way stations for those journeying to Chaco. Many of the more than 200,000 timbers used in the construction of Chacoan great houses came from the Chuskas (English et al., 2001). In addition, the Chuskas were a source of high-quality Narbona Pass chert used to make flaked stone tools (Cameron, 2001) and also were a source of large quantities of Chaco's pottery, for example, gray ware (Toll, 1991and references therein).

Friedman et al. (2003) have documented the existence of three ancient (but undated) agricultural field systems on the Chuska Slope near the present location of Newcomb, New Mexico. One of the Newcomb field systems has $74 \mathrm{~km}$ of main ditches, is $6.9 \mathrm{~km}$ long, $2.8 \mathrm{~km}$ wide, and covers an area of $8.0 \mathrm{~km}^{2}$ ( $\sim 2000$ acres). Today rural Mesoamericans consume between 95 and $161 \mathrm{~kg}$ of dried maize in a year (940-1590 kcal/day) (Stuart, 1990). If the $8.0 \mathrm{~km}^{2}$ Newcomb field produced 5 bushels $(127 \mathrm{~kg}$ ) of maize per acre, it would have yielded a total $254,000 \mathrm{~kg}$ of maize/yr. This single field system could, therefore, supply the annual maize requirement of between 1600 and 2700 Pre-Columbian individuals and may have, in combination with the other two Newcomb fields, functioned as the prehistoric breadbasket of the Chaco Canyon community.

Agricultural support of the inhabitants of Chaco Canyon probably differed before and after the Collapse of the Chacoan world. In the following, two time periods will be considered. From the time of the initial construction of Pueblo Bonito (A.D. 860) until the beginning of the middle-twelfth-century megadrought (A.D. 1130), populations expanded across the study area. This was a time when people outside the Canyon may have visited Chaco for ritual feasting. Windes (1984) and Lekson (1986) have suggested that between about 2000 and 3000 people inhabited the Canyon in its heyday; i.e., A.D. 1020-1130. If so, maize grown within the Canyon area would not have been sufficient to support this large number of people (see for example, Benson, 2011a,b; Benson et al., 2006b).

The second period of interest occurred between the beginning of the mid-twelfth-century megadrought (A.D. 1130) and the beginning of the late-thirteenth-century megadrought (A.D. 1270). Shortly before A.D. 1130, the Chaco Canyon elite are thought to have moved north to Aztec Ruins (Fig. 1) where they established a new political center (Morris, 1921). Chacoans also may have migrated south to the Zuni region during the early 1100s (Kintigh et al., 2004). In any case, after A.D. 1130, only a small population occupied Chaco Canyon. The construction activities of these "squatters" indicate a return to small domestic units and small-house architecture and involved the widespread reuse of great house building stone and timbers (Toll, 1985; Windes, 2003). Given their small numbers, and the collapse of the Chacoan political system, one might expect that after A.D. 1130 the residents of the Canyon would have depended on the cultivation of maize in nearby field settings.

\section{Methods and strategies used to source archaeological maize cobs}

Over the past seven years, my colleagues and I have attempted to link archaeological cobs to the fields in which they were grown using three geochemical approaches: (1) Sr isotopes, (2) the partitioning of trace metals between soil water and cob, and (3) $\mathrm{Pb}$ isotopes. Each geochemical approach requires extraction of biologically available trace metals (for example $\mathrm{Sr}, \mathrm{Pb}$ ) present in agricultural soil waters. Such trace metals can be obtained from the bones of mammals with different home ranges (for example, mice, rabbits, deer), from plants (especially those with rooting depths similar to the rooting depth of corn $[<1.5 \mathrm{~m}]$ ), and from soil water.

Because we wished to test whether corn cobs incorporated some trace-metal pairs in a systematic fashion, we elected to work with soil waters from potential agricultural field systems. However, we did not want to go through the time-consuming process of collecting natural soil waters, using lysimeters or other waterextraction apparatus; therefore, we created synthetic soil waters by leaching the soils with a weak acid.

\subsection{Extraction of $\mathrm{Sr}$ isotopes from soils and cobs: early approaches}

In Benson et al. (2003), we first tested the ability of synthetic soil water to duplicate the ${ }^{87} \mathrm{Sr} /{ }^{86} \mathrm{Sr}$ ratios of maize cobs grown in those soils. Synthetic soil water that is truly representative of natural soil water is one that contains the same ratio of bioavailable metals and isotopes found in the natural soil water. In the semi-arid American Southwest, bioavailable soil-water metals are thought to mostly reside in soluble carbonate minerals and on ion-exchange sites in expandable clays. In order to extract $\mathrm{Sr}$ from these two sources and to avoid extracting $\mathrm{Sr}$ from more refractory mineral sources (such as aluminosilicates) we experimented with weak- and dilute-acid soil leaches. Hopi Blue maize grown in experimental gardens at the Crow Canyon Archaeological Research Center at Cortez, Colorado, (Hovezak, 1993) and the New Mexico State University Agricultural Science Center at Los Lunas, New Mexico (Muenchrath, 1995) were obtained from archival collections along with samples of the soil in which they grew. 


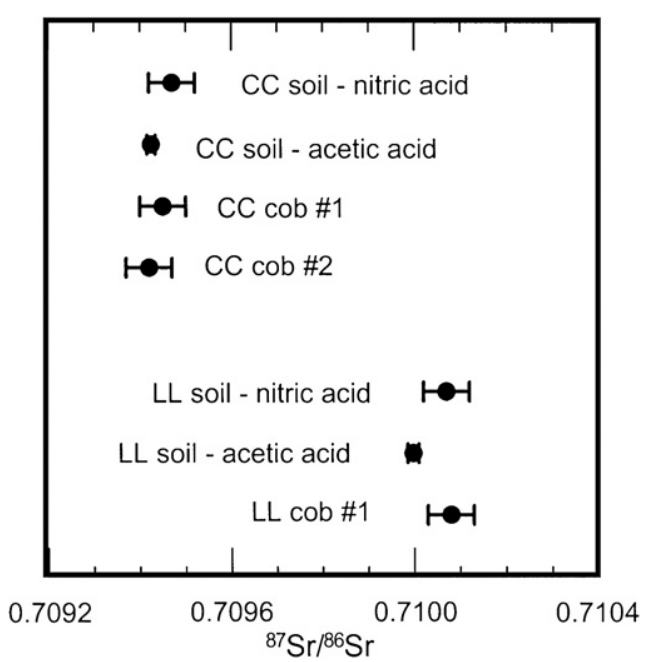

Fig. 6. Strontium-isotope ratios of cobs and synthetic soil waters from which the cobs grew. Cobs were taken from Crow Canyon (CC) and Los Lunas (LL) experimental gardens.

Synthetic soil waters were produced by leaching soils with $1 \%$ nitric acid or 1-M acetic acid, and the cobs were ashed and dissolved in 3-N nitric acid prior to chemical analysis. The results of this experiment indicated excellent agreement between the ${ }^{87} \mathrm{Sr} /{ }^{86} \mathrm{Sr}$ ratios of the synthetic soil waters and the cobs grown from those soils (Fig. 6). Therefore, an acetic-acid leach was used in all subsequent research; i.e., in order to produce synthetic soil waters, soils collected in all studies that followed were air dried, homogenized, and a 5-g subsample of each soil was leached for $48 \mathrm{~h}$ with constant agitation using $500 \mathrm{ml}$ of 1-M acetic acid prepared from distillation-purified glacial-acetic acid. These samples were sequentially filtered through $0.4-$ and $0.1-\mu \mathrm{m}$ pore-size membrane filters prior to chemical analysis.

Cob processing prior to isotopic analysis was accomplished using the following procedure (Benson et al., 2003). The center $4 \mathrm{~cm}$ of each cob was removed using a titanium knife. To remove mineral contaminants, the kernels and cupules were physically removed using a titanium or ceramic knife, discarded, and the remaining cob was cut into small pieces, homogenized, and freeze dried. A 0.9- to 4.2-g subsample was transferred to a clean platinum crucible for dry ashing in a muffle furnace. Ashing was accomplished by ramping the temperature of the furnace in $50{ }^{\circ} \mathrm{C}$ increments every $30 \mathrm{~min}$ from a starting temperature of $100^{\circ} \mathrm{C}$ to a final temperature of $450^{\circ} \mathrm{C}$ at which temperature the sample was kept for $16 \mathrm{~h}$. After cooling to room temperature, the sample was transferred to a small Teflon vessel to which $2 \mathrm{ml}$ of DI water, $0.5 \mathrm{ml}$ of high-purity concentrated $\mathrm{HNO}_{3}, 1.5 \mathrm{ml}$ of high-purity $\mathrm{HCl}$, and $1 \mathrm{ml}$ of HF acid were added. This solution was then evaporated to dryness on a sand bath. The residue was dissolved in $2 \mathrm{ml}$ of concentrated $\mathrm{HNO}_{3}$, evaporated on a sand bath, and the procedure repeated; then $10 \mathrm{ml}$ of DI water and $1 \mathrm{ml}$ of $\mathrm{HNO}_{3}$ were added to the vessel which was gently heated on the sand bath to near dryness. The residue was then diluted with $100 \mathrm{ml}$ of DI water in a volumetric flask.

In this and other studies discussed in this paper, Strontium chemical separations and isotopic determinations were conducted in a Class 1-10,000 clean room. Strontium separates were obtained using a Sr-specific resin ( $\mathrm{Sr}$ resin SPS, Eichrom Technologies, Inc.). The total procedural blank for $\mathrm{Sr}$ was $\sim 30 \mathrm{pg}$. Strontium isotopic measurements were obtained using a Finnigan-MAT 261 thermalionization mass spectrometer in 4-collector static mode. Thirtyone measurements of the SRM-987 Sr isotopic standard yielded a mean ${ }^{87} \mathrm{Sr} /{ }^{86} \mathrm{Sr}$ value of $0.71028 \pm 0.00002(2 \sigma$-mean $)$ which is identical, within the precision of the measurement (two parts in the fifth decimal place), to the reference value of the standard (0.71028).

In a subsequent paper (Benson, 2010), the ${ }^{87} \mathrm{Sr} /{ }^{86} \mathrm{Sr}$ ratios of cobs from four different Southwestern Native American landraces were compared with the ${ }^{87} \mathrm{Sr} /{ }^{86} \mathrm{Sr}$ ratios of their synthetic soils waters produced using 1-M acetic acid. The data indicated that the difference between the ${ }^{87} \mathrm{Sr} /{ }^{86} \mathrm{Sr}$ ratios of the cobs and their soil waters ranged from 0 to 4 units in the fourth decimal place (Table 2 in Benson, 2010) and supported the use of acetic acid to produce representative synthetic soil waters.

\subsection{Trace-metal extractions from soils}

In Benson et al. (2003), an attempt was made, using a limited number of cob and soil samples, to determine if trace metals partitioned systematically from soil water into maize cobs. The partitioning or distribution coefficient $\left(K_{\mathrm{D}}\right)$ between soil water and a cob can be expressed by

$K_{\mathrm{D}}\left(C_{T M 1} / C_{T M 2}\right)_{\text {Soil Water }}=\left(C_{T M 1} / C_{T M 2}\right)_{\mathrm{Cob}}$

in which $C_{T M n}$ is the concentration ( $\mu \mathrm{g} / \mathrm{g}$ ) of trace metal $n$ in the soil water or cob. In the Benson et al. (2003) study, three metal pairs $(\mathrm{Ba} / \mathrm{Sr}, \mathrm{Mg} / \mathrm{Sr}$, and $\mathrm{Y} / \mathrm{Yb}$ ) showed some promise in this respect.

In Benson (2010) a more rigorous experiment was conducted in order to determine which metal pairs obeyed Equation (1). Five of 155 Native American maize landraces grown at New Mexico State University's (NMSU) Agricultural Science Center at Farmington, New Mexico, during the summer of 2005 (Adams et al., 2006) were studied. Two cobs each were picked from 10 plants of each of the five landraces. The sampled maize accessions include landraces from three Native American groups (Acoma, Hopi, and Zuni) that still occupy the study area. These landraces were chosen because they may be similar to those grown by pre-Columbian Native Americans that occupied parts of the study area between A.D. 850 and 1300 . Prior to metals analysis, approximately 30 kernels each from the Hopi Blue and Zuni Blue cobs, both of the flour (endosperm) variety, were prepared in the same manner as the cobs.

Soils were collected from the bases of the five Native American maize landraces (10 plants from each of the five landraces). A 7.5$\mathrm{cm}$-diameter soil auger was used to obtain representative soil samples from both sides of maize stalks at depths centered at 35 and $70 \mathrm{~cm}$. These two sample depths were chosen because they fall within the rooting depth $(\sim 1.5 \mathrm{~m})$ of maize. All four soil samples were placed within a single Ziploc plastic bag and homogenized in the lab.

Metals were extracted from the soils using 1-M acetic acid and the cob samples were processed and ashed in the manner described previously. Multi-element trace-metal determinations were performed using inductively coupled plasma-mass spectrometric (ICPMS and ICP-AES) methods. All measurements were made on aqueous sample solutions without preconcentration, using direct pneumatic nebulization with a Perkin-Elmer Elan 6000 instrument. ICP-MS and ICP-AES analyses were done for 51 trace metals for maize samples and 52 trace metals for synthetic soil waters.

The cobs contained 36 metals that were significantly above their detection limits; the kernels contained 24 detectable metals, and the soil waters contained 38 detectable metals. Using a program embedded in EXCEL software, all possible metal-ratio values for cobs, kernels, and soil waters were calculated. $K_{\mathrm{D}} \mathrm{s}$ for soil water:cob and soil water:kernel metal pairs were calculated, using five cob landraces and two kernel landraces. Using the criteria that the standard deviation of a metal pair $K_{\mathrm{D}}$ for a particular landrace had to be $\leq 33 \%$ of its mean value (variance 
Table 1

Distribution coefficient values for six metal pairs and five cob landraces and for four metal pairs in two kernal landraces.

\begin{tabular}{|c|c|c|c|c|c|c|c|c|c|c|c|c|}
\hline Maize cob type & $K_{\mathrm{D}}(\mathrm{Ba} / \mathrm{Mn})$ & $1-\sigma$ & $K_{\mathrm{D}}(\mathrm{Ba} / \mathrm{Sr})$ & $1-\sigma$ & $K_{\mathrm{D}}(\mathrm{Ca} / \mathrm{Sr})$ & $1-\sigma$ & $K_{\mathrm{D}}(\mathrm{K} / \mathrm{Rb})$ & $1-\sigma$ & $K_{\mathrm{D}}(\mathrm{Eu} / \mathrm{Gd})$ & $1-\sigma$ & $K_{\mathrm{D}}(\mathrm{Y} / \mathrm{Yb})$ & $1-\sigma$ \\
\hline Acoma yellow & 0.067 & 0.021 & 0.285 & 0.058 & 0.121 & 0.030 & 4.00 & 1.11 & 1.26 & 0.38 & 0.84 & 0.31 \\
\hline Acoma orange/yellow & 0.067 & 0.017 & 0.243 & 0.063 & 0.141 & 0.050 & 3.48 & 0.70 & 1.24 & 0.27 & 0.72 & 0.11 \\
\hline Acoma white/red & 0.077 & 0.022 & 0.214 & 0.065 & 0.179 & 0.041 & 3.97 & 0.84 & 1.17 & 0.27 & 0.71 & 0.11 \\
\hline Hopi blue & 0.069 & 0.029 & 0.217 & 0.036 & 0.144 & 0.031 & 5.21 & 0.97 & 1.31 & 0.31 & 0.67 & 0.13 \\
\hline Zuni blue & 0.078 & 0.027 & 0.230 & 0.048 & 0.171 & 0.030 & 4.68 & 2.05 & 1.17 & 0.40 & 0.79 & 0.17 \\
\hline Mean and Variability & 0.072 & 0.024 & 0.24 & 0.06 & 0.15 & 0.04 & 4.27 & 1.35 & 1.23 & 0.33 & 0.75 & 0.19 \\
\hline Maize kernel type & \multicolumn{2}{|c|}{$K_{\mathrm{D}}(\mathrm{Ba} / \mathrm{Rb})$} & $1-\sigma$ & \multicolumn{2}{|c|}{$K_{\mathrm{D}}(\mathrm{Ba} / \mathrm{Sr})$} & $1-\sigma$ & \multicolumn{2}{|c|}{$K_{\mathrm{D}}(\mathrm{Mg} / \mathrm{P})$} & $1-\sigma$ & \multicolumn{2}{|c|}{$K_{\mathrm{D}}(\mathrm{Mn} / \mathrm{P})$} & $1-\sigma$ \\
\hline Hopi blue & \multicolumn{2}{|l|}{0} & 0 & \multicolumn{2}{|l|}{0.35} & 0.13 & \multicolumn{2}{|l|}{0.05} & 0.010 & \multicolumn{2}{|c|}{0.01} & 0 \\
\hline Zuni blue & \multicolumn{2}{|l|}{0} & 0 & \multicolumn{2}{|l|}{0.27} & 0.06 & \multicolumn{2}{|l|}{0.05} & 0.01 & \multicolumn{2}{|c|}{0.01} & 0 \\
\hline Mean and Variability & \multicolumn{2}{|c|}{0.00021} & 0 & \multicolumn{2}{|l|}{0.31} & 0.11 & \multicolumn{2}{|l|}{0.05} & 0.01 & \multicolumn{2}{|c|}{0.0068} & 0.0015 \\
\hline
\end{tabular}

arbitrarily selected), it was determined that four metal pairs (Ba/ $\mathrm{Mn}, \mathrm{Ba} / \mathrm{Sr}, \mathrm{Ca} / \mathrm{Sr}$, and $\mathrm{K} / \mathrm{Rb}$ ) exhibited systematic distribution coefficients between soil waters and cobs and that four metal pairs ( $\mathrm{Ba} / \mathrm{Rb}, \mathrm{Ba} / \mathrm{Sr}, \mathrm{Mg} / \mathrm{P}$, and $\mathrm{Mn} / \mathrm{P}$ ) exhibited systematic distribution coefficients between soil waters and kernels for all landraces studied (Table 1 ).

\subsection{The evolution of cob processing methods}

In Benson et al. (2010), we attempted to expand our research to include isotopic and metals analyses of burned cobs. Most archaeological cobs are at least partially burned and have lost up to $75 \%$ of their mass. Partially burned organic materials present a particular problem because they often incorporate inorganic contaminants during incomplete combustion. Burned organic materials can also act as activated charcoal, adsorbing inorganic metals during their tenure in fire pits, storage caches, or other depositional settings. In addition, unburned archaeological cobs are often coated with construction debris, dust, or soil which contains mineral particles.

The measurement of ${ }^{87} \mathrm{Sr} /{ }^{86} \mathrm{Sr}$ ratios of organic archaeological materials requires that the sample be essentially free of inorganic contaminants containing the metal $\mathrm{Sr}$. This is because strong acids such as HF used to dissolve an organic sample ashed prior to chemical analysis will also dissolve any residual mineral contaminant and will yield a ${ }^{87} \mathrm{Sr} /{ }^{86} \mathrm{Sr}$ value which, to a greater or lesser extent, reflects the ${ }^{87} \mathrm{Sr} /{ }^{86} \mathrm{Sr}$ value of the contaminant.

In order to remove contaminant dust and soil from burned archaeological cobs, we chose to follow a procedure somewhat similar to that employed by palynologists to remove minerals from sediment samples prepared for pollen and charcoal analyses. The pollen cleaning procedure uses $\mathrm{KOH}$ to disaggregate the sediment and remove humic acids, $\mathrm{HCl}$ to remove carbonate minerals, and $\mathrm{HF}$ to remove silicate minerals (Faegri and Iverson, 1975). Because $\mathrm{KOH}$ contains metal contaminants we chose not to apply it to the burned cobs.

Ten burned cobs from Salmon Ruins were selected for the first experiment. The procedure used to clean burned cobs from Salmon Ruins consisted of the following steps. About $1-\mathrm{cm}^{3}$ of each cob was weighed, crushed, and homogenized in an agate mortar and pestle. The crushed sample was quantitatively transferred to a $50-\mathrm{ml}$ polycarbonate centrifuge tube using deionized (DI) water. About $20 \mathrm{ml}$ of $10 \%$ high-purity $\mathrm{HCl}$ was added to the centrifuge tube and the suspension was shaken and let sit overnight. The sample was then centrifuged at $5000 \mathrm{rpm}$ for $10 \mathrm{~min}$. The supernatant liquid was decanted to waste. DI water was added to the centrifuge tubes and they were spun at $5000 \mathrm{rpm}$ for $10 \mathrm{~min}$ and the rinse solution discarded. The DI rinse was repeated twice more to ensure removal of Ca. Twenty $\mathrm{ml}$ of $50 \% \mathrm{HF}$ was added to the sample; the sample was then shaken and let sit for $48 \mathrm{~h}$. The sample was then centrifuged at $5000 \mathrm{rpm}$ for $10 \mathrm{~min}$ and the supernatant was decanted to waste. DI water was added to the centrifuge tube(s) which were balanced and centrifuged at $5000 \mathrm{rpm}$ for $10 \mathrm{~min}$ and the rinse solution discarded. The DI water rinse was repeated twice more. A weighing boat was then tared and the extracted sample was transferred to the boat and air dried in a laminar flow hood. The weight of the preprocessed dried corn-cob sample was then determined and the sample was transferred to a platinum crucible and the weight of the crucible and the sample determined. The sample was then ashed in a muffle furnace by ramping the temperature of the furnace in $50{ }^{\circ} \mathrm{C}$ increments every $30 \mathrm{~min}$ from a starting temperature of $100{ }^{\circ} \mathrm{C}$ to a final temperature of $450{ }^{\circ} \mathrm{C}$ at which temperature the sample was kept for $16 \mathrm{~h}$. After cooling to room temperature, the sample was transferred to a small Teflon vessel to which $2.0 \mathrm{ml}$ of DI water, $0.5 \mathrm{ml}$ of high-purity $\mathrm{HNO}_{3}$, $1.5 \mathrm{ml}$ of high-purity $\mathrm{HCl}$, and $1.0 \mathrm{ml}$ of $\mathrm{HF}$ were added. The solution was then evaporated to dryness on a sand bath, the residue dissolved in $2 \mathrm{ml}$ of concentrated $\mathrm{HNO}_{3}$ and the procedure repeated. Then $10 \mathrm{ml}$ of DI water and $1 \mathrm{ml}$ of $\mathrm{HNO}_{3}$ were added to the vessel which was gently heated on the sand bath to near dryness. The residue was then diluted with $100 \mathrm{ml}$ of DI water in a volumetric flask.

Aluminum values of the 10 cobs range from 2 to $1356 \mu \mathrm{g} / \mathrm{g}$ in the first experiment, indicating that some of the cobs remained contaminated with aluminosilicates after the HF treatment. Because some of the Al values were elevated, four burned Salmon Ruins cobs were processed in a second experiment. The cleaning procedure applied to the second set of Salmon Ruins cobs differed from the procedure itemized above in the number of rinses after the application of $\mathrm{HCl}$ (six rinses) and $\mathrm{HF}$ (four rinses). This was done to remove mineral matter dissolved by the acids. However, Al values of the second set of Salmon cobs were not substantially reduced, indicating that some silicate debris probably remained in the ashed samples. When the ${ }^{87} \mathrm{Sr} /{ }^{86} \mathrm{Sr}$ values of partially cleaned burned Salmon Ruins cobs were plotted versus their Al concentrations, they converged on the ${ }^{87} \mathrm{Sr} /{ }^{86} \mathrm{Sr}$ values of synthetic soil waters from the Salmon Ruins site (Fig. 7), suggesting that if aluminosilicate contaminants could be completely removed, the ${ }^{87} \mathrm{Sr} /{ }^{86} \mathrm{Sr}$ value of the ashed cob would reflect the ${ }^{87} \mathrm{Sr} /{ }^{86} \mathrm{Sr}$ value of the soil in which it was grown.

In the third and final experiment, 10 burned cobs from Aztec Ruins, New Mexico, were processed. We adopted the hypothesis that, to this point, some silicate particles were escaping the initial HF treatment and multiple rinses and remained present when the cobs were ashed. Thus, when HF was added to the ashed cob samples, some of the residual aluminosilicate contaminants were put into solution, yielding the elevated Al values. Therefore, in the third experiment, the rate of centrifugation was increased to $10,000 \mathrm{rpm}$ and we omitted HF from the group of acids added to the ashed sample(s), preventing the dissolution of residual 


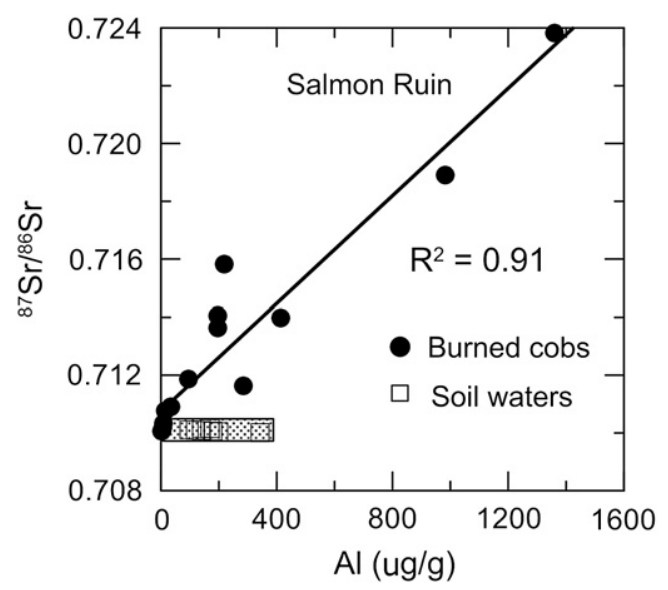

Fig. 7. Strontium-isotope ratios of partially cleaned burned cobs from Salmon Ruins, New Mexico, as a function of Al content. Shaded area encloses ${ }^{87} \mathrm{Sr} /{ }^{86} \mathrm{Sr}$ ratios of soilleachate waters from Salmon Ruin.

aluminosilicate material. Visible particles in the acidified and ashed samples were removed by filtration. Analyses of the 10 Aztec cobs indicated that $\mathrm{Al}$ was present at very low levels $(\leq 32 \mu \mathrm{g} / \mathrm{g})$ and that the great majority of the contaminant aluminosilicate fraction had been eliminated from the burned archaeological cobs. In addition, the low-Al Aztec Ruins burned cobs had ${ }^{87} \mathrm{Sr} /{ }^{86} \mathrm{Sr}$ values similar to the ${ }^{87} \mathrm{Sr} /{ }^{86} \mathrm{Sr}$ values of synthetic soil waters from that site, which also indicated that the burned cobs were essentially free of mineral contaminants (Fig. 8).

\subsection{The cleaning of contaminated unburned archaeological cobs}

The experiments with burned archaeological cobs created a renewed awareness of mineral contamination and the ability of $\mathrm{Al}$ to signal the presence of contamination of certain mineral phases. For example, Al concentrations in many of the archeologic cobs analyzed in our early studies (Table 2) exceed the Al values of modern cobs produced at NMSU's Agricultural Science Center. One hundred modern cobs from the Benson et al. (2008) study had $\mathrm{Al}$ values ranging from 1.4 to $17 \mu \mathrm{g} / \mathrm{g}$ with a mean value of $4.9 \pm 4.4 \mu \mathrm{g}$ / g. Therefore, we decided to apply our burned cob cleaning procedure to 10 unburned cobs found in Gallo Cliff Dwelling (Benson et al., 2010).

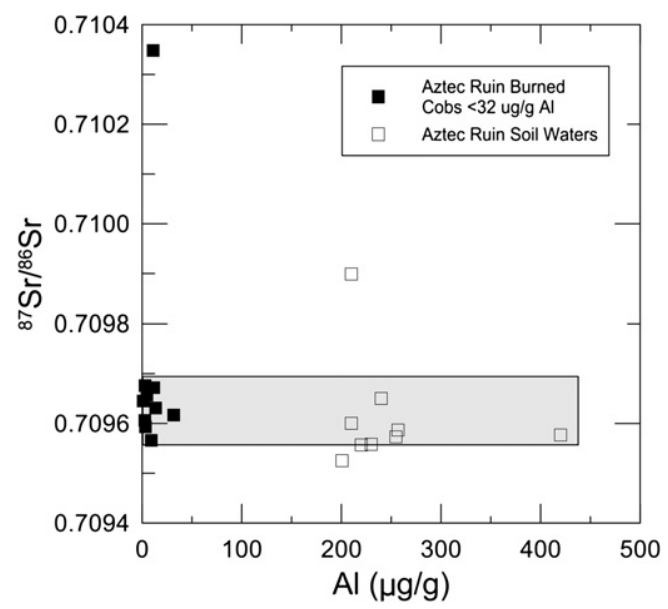

Fig. 8. Strontium-isotope ratios of cleaned, low-Al, burned cobs from Aztec Ruins compared with ${ }^{87} \mathrm{Sr} /{ }^{86} \mathrm{Sr}$ ratios of synthetic soil waters (leachates) from the Aztec Ruin site.
The data from this experiment indicated that the 10 cleaned cobs had $\mathrm{Al}$ and $\mathrm{Sr}$ values that were approximately two orders of magnitude less than the $\mathrm{Al}$ and $\mathrm{Sr}$ values of previously analyzed Gallo Cliff Dwelling cobs (Benson et al., 2009). In addition, the Sr values of the cleaned cobs were one order of magnitude less than $\mathrm{Sr}$ values obtained on modern clean Southwestern Native American landraces (Supplementary Table 1 in Benson et al., 2008), indicating a substantial loss of weakly bound metals from the processed cobs.

The ${ }^{87} \mathrm{Sr} /{ }^{86} \mathrm{Sr}$ ratios of the cleaned cobs were substantially larger than the ${ }^{87} \mathrm{Sr} /{ }^{86} \mathrm{Sr}$ ratios measured on the previously analyzed Gallo Cliff Dwelling cobs, and Sr values were highly correlated with Al values in the cleaned cobs. This indicated that $\mathrm{Sr}$ and $\mathrm{Al}$ in the cleaned cobs did not, for the most part, derive from the organic matter comprising the cob; i.e., the $\mathrm{Sr}$ and $\mathrm{Al}$ in the cleaned cobs derived from residual mineral contamination, either a single mineral (or mineral colloid) or a homogeneous mixture of minerals with a fixed $\mathrm{Sr} / \mathrm{Al}$ ratio. This suggestion is supported by the fact that the ${ }^{87} \mathrm{Sr} /{ }^{86} \mathrm{Sr}$ ratio of the cleaned cobs also increased with increasing $\mathrm{Al}$; i.e., with increasing mineral content of the sample. It appeared therefore that the cleaning process had stripped the unburned archaeological cobs of their organically bound metals and that a small amount of Sr-containing mineral matter or mineral colloid escaped the filtration step that preceded chemical analysis. These results suggested that the multiple-acid cleaning process could not be successfully applied to mineral-contaminated, unburned archaeological cobs.

One problem in the use of metals to "source" organic materials is the fact that most metals are not tightly bound to the plant. The cob's surface is cellulose based and the parts that contact water are negatively charged (Biermann, 1996). Maize cobs are composed of aligno-cellulosic material with a large number and array of different functional oxygen groups that have negative charge (Nassar, 2006). Cellulose and hemicellulose make up, respectively, 50 and $26 \%$ of cobs. Cellulose is a polysaccharide (a form of carbohydrate) that makes up the plant cell wall and is composed of glucose. Acid polysaccharides have carboxyl groups. Natural cellulose contains several ionizable functional (carboxyl and hydroxyl) groups and; therefore, acts as a weak ion-exchange substrate. Crude polysaccharides in corn cobs contain two functional groups; the carboxyl group has a strong affinity for cations and the hydroxyl group has a weak affinity (Lehrfeld, 1996).

Thus, if a cob acts as an organic ion-exchange substrate, a laboratory procedure that includes rinsing or submerging a cob in DI water (or a sequence of acids) may result in metal loss to the water. In order to determine the magnitude and stoichiometry of metal loss, we submerged small $(<5 \mathrm{~mm})$ pieces of three freeze-dried cobs in DI water for up to $24 \mathrm{~h}$. About one-third of the pieces were weighed, secured in a pre-cleaned nylon mesh bag, and put into a pre-cleaned Teflon beaker to which $250 \mathrm{ml}$ of DI water was added. The stirred solution was sampled (2-20 ml samples) at intervals of $2,5,15,60$, and $1440 \mathrm{~min}$, using a syringe with attached filter. The filtrate was transferred to a sample bottle and acidified with nitric acid. The paired samples were then combined and triplicate ICP-MS and ICP-AES analysis performed on the $40 \mathrm{ml}$ samples.

A set of cob fragments, which were not subjected to the leaching experiment, were frozen, freeze dried, ashed, the ash dissolved, and the solution analyzed via ICP-MS and ICP-AES. The data resulting from this experiment was used to determine the rate of loss of trace metals from the cob over the 24-h experiment and the total loss of metals from the cob during the experiment. The data indicate that some fraction of all metals was transferred from the cob to the water (Benson et al., 2010).

We were particularly interested in the effect of metal loss on the ratios of four metal pairs $(\mathrm{Ba} / \mathrm{Mn}, \mathrm{Ba} / \mathrm{Sr}, \mathrm{Ca} / \mathrm{Sr}$, and $\mathrm{K} / \mathrm{Rb})$ that we 
Table 2

Archaeological cob provenience, age, ${ }^{87} \mathrm{Sr} /{ }^{86} \mathrm{Sr}$ ratio, $\mathrm{Al}$, and $\mathrm{Sr}$ concentration.

\begin{tabular}{|c|c|c|c|c|c|c|c|c|}
\hline \multirow[t]{2}{*}{ Site No. } & \multirow[t]{2}{*}{ Site Name } & \multirow{2}{*}{$\frac{\text { Cal. Age Midpt. }}{(1 \sigma \text { AD })}$} & \multirow[t]{2}{*}{${ }^{87} \mathrm{Sr} /{ }^{86} \mathrm{Sr}$} & \multirow{2}{*}{$\frac{{ }^{87} \mathrm{Sr} /{ }^{86} \mathrm{Sr} \text { Error }}{( \pm 2 \sigma)}$} & \multirow{2}{*}{$\frac{\mathrm{Al}(\mu \mathrm{g} / \mathrm{g})}{( \pm 1 \sigma)}$} & \multirow{2}{*}{$\frac{\mathrm{Sr}(\mu \mathrm{g} / \mathrm{g})}{( \pm 1 \sigma)}$} & \multirow{2}{*}{$\frac{\mathrm{Ca}(w \mathrm{t} \%)}{( \pm 1 \sigma)}$} & \multirow{2}{*}{$\frac{M g(w t \%)}{( \pm 1 \sigma)}$} \\
\hline & & & & & & & & \\
\hline \multicolumn{9}{|l|}{ Aztec Ruin Cobs } \\
\hline AZRU 533A & East Room P15 & & 0.709848 & 0.000011 & $200 \pm 10$ & $16.8 \pm 0.3$ & $0.12 \pm 0.02$ & $0.053 \pm 0.007$ \\
\hline AZRU 533B & East Room P15 & & 0.710119 & 0.000010 & $58 \pm 4$ & $5.1 \pm 0.5$ & $0.038 \pm 0.002$ & $0.066 \pm 0.002$ \\
\hline AZRU 1052 & East Room 11 & & 0.710166 & 0.000034 & $96 \pm 16$ & $8.2 \pm 0.7$ & $0.078 \pm 0.001$ & $0.090 \pm 0.001$ \\
\hline AZRU 1057 & East Room 14 & & 0.710312 & 0.000019 & $200 \pm 10$ & $7.4 \pm 0.3$ & $0.079 \pm 0.004$ & $0.026 \pm 0.002$ \\
\hline AZRU 3853 & East Room 12 & & 0.709801 & 0.000015 & $130 \pm 10$ & $5.1 \pm 0.4$ & $0.35 \pm 0.004$ & $0.032 \pm 0.000$ \\
\hline AZRU 3921 & West Room 224 & & 0.709791 & 0.000012 & $63 \pm 5$ & $10.8 \pm 0.6$ & $0.065 \pm 0.000$ & $0.055 \pm 0.001$ \\
\hline AZRU 9341 & West Room 225 & & 0.710062 & 0.000012 & $87 \pm 12$ & $8.9 \pm 0.8$ & $0.050 \pm 0.001$ & $0.032 \pm 0.002$ \\
\hline AZRU 9438 & West Room 225 & & 0.709705 & 0.000016 & $110 \pm 0$ & $20 \pm 2$ & $0.161 \pm 0.000$ & $0.098 \pm 0.000$ \\
\hline AZRU 9651 & West Room 225 & & 0.709977 & 0.000012 & $1100 \pm 60$ & $92 \pm 4$ & $0.093 \pm 0.02$ & $0.334 \pm 0.001$ \\
\hline AZRU 11091 & West Room 186 & & 0.709694 & 0.000015 & $210 \pm 10$ & $62 \pm 4$ & $0.412 \pm 0.001$ & $0.140 \pm 0.002$ \\
\hline \multicolumn{9}{|c|}{ Pueblo Bonito Cobs } \\
\hline H10648 & Room 170 & $1007 \pm 33$ & 0.709892 & 0.000016 & $131 \pm 0$ & $2.2 \pm 0.2$ & $0.016 \pm 0.000$ & $0.035 \pm 0.000$ \\
\hline $\mathrm{H} 242 / 244 \mathrm{~A}$ & Room 3 & $996 \pm 27$ & 0.709319 & 0.000016 & $52 \pm 5$ & $4.6 \pm 0.3$ & $0.032 \pm 0.001$ & $0.054 \pm 0.003$ \\
\hline $\mathrm{H} 242 / 244 \mathrm{~B}$ & Room 3 & $994 \pm 27$ & 0.709475 & 0.000042 & $170 \pm 20$ & $5.5 \pm 0.3$ & $0.042 \pm 0.002$ & $0.015 \pm 0.001$ \\
\hline $\mathrm{H} 254 / 258 \mathrm{~A}$ & Room 3 & $1181 \pm 30$ & 0.709394 & 0.000010 & $160 \pm 10$ & $18 \pm 1$ & $0.15 \pm 0.01$ & $0.040 \pm 0.002$ \\
\hline H254/258B & Room 3 & $972 \pm 25$ & 0.709225 & 0.000018 & $50 \pm 7$ & $2.8 \pm 0.2$ & $0.018 \pm 0.002$ & $0.020 \pm 0.001$ \\
\hline $\mathrm{H} 254 / 258 \mathrm{C}$ & Room 3 & $832 \pm 53$ & 0.709280 & 0.000014 & $1000 \pm 60$ & $5.5 \pm 0.5$ & $0.023 \pm 0.001$ & $0.018 \pm 0.000$ \\
\hline H7673 & Room 92 & $1214 \pm 45$ & 0.709328 & 0.000011 & $230 \pm 0$ & $12 \pm 1$ & $0.119 \pm 0.001$ & $0.081 \pm 0.001$ \\
\hline \multicolumn{9}{|c|}{ Other Chaco Canyon Cobs } \\
\hline CHCU2081-1 & Una Vida & & 0.709401 & 0.000009 & $3140 \pm 21$ & $412 \pm 5$ & $3.47 \pm 0.05$ & $0.203 \pm 0.002$ \\
\hline CHCU32288-1 & Chetro Ketl Room 92 & $1183 \pm 27$ & 0.709523 & 0.000014 & $131 \pm 7$ & $\mathbf{1 1} \pm \mathbf{0}$ & $0.110 \pm 0.000$ & $0.015 \pm 0.001$ \\
\hline CHCU32288-2 & Chetro Ketl Room 92 & $1186 \pm 23$ & 0.709350 & 0.000009 & $91 \pm 2$ & $22 \pm 0$ & $0.212 \pm 0.005$ & $0.053 \pm 0.001$ \\
\hline CHCU32289-1 & Chetro Ketl Room 92 & $1186 \pm 23$ & 0.709547 & 0.000015 & $700 \pm 0$ & $23 \pm 0$ & $0.242 \pm 0.008$ & $0.056 \pm 0.001$ \\
\hline CHCU32299-1 & Kin Kletso & $1238 \pm 16$ & 0.710747 & 0.000010 & $1960 \pm 35$ & $53 \pm 0$ & $0.823 \pm 0.007$ & $0.35 \pm 0.03$ \\
\hline CHCU32999-1 & Kin Kletso & $1194 \pm 24$ & 0.709258 & 0.000015 & $1190 \pm 49$ & $228 \pm 1$ & $3.426 \pm 0.001$ & $0.41 \pm 0.01$ \\
\hline CHCU32999-2 & Kin Kletso & $1183 \pm 27$ & 0.709280 & 0.000012 & $928 \pm 3$ & $322 \pm 1$ & $3.55 \pm 0.14$ & $0.21 \pm 0.01$ \\
\hline CHCU43684-1 & Gallo Cliff Dwelling & $1195 \pm 25$ & 0.710880 & 0.000014 & $243 \pm 10$ & $3.4 \pm \mathbf{0 . 1}$ & $0.051 \pm 0.001$ & $0.089 \pm 0.003$ \\
\hline CHCU43684-2 & Gallo Cliff Dwelling & $1198 \pm 21$ & 0.711062 & 0.000014 & $517 \pm 2$ & $6.8 \pm 0.1$ & $0.078 \pm 0.001$ & $0.143 \pm 0.003$ \\
\hline CHCU43684-3 & Gallo Cliff Dwelling & $1194 \pm 24$ & 0.709638 & 0.000011 & $106 \pm 2$ & $4.7 \pm 0.1$ & $0.036 \pm 0.000$ & $0.107 \pm 0.004$ \\
\hline CHCU43684-4 & Gallo Cliff Dwelling & $1070 \pm 25$ & 0.709770 & 0.000011 & $366 \pm 8$ & $9.7 \pm 0.1$ & $0.133 \pm 0.006$ & $0.122 \pm 0.003$ \\
\hline CHCU43684-5 & Gallo Cliff Dwelling & $1183 \pm 27$ & 0.709586 & 0.000015 & $50 \pm 2$ & $4.1 \pm 0.0$ & $0.032 \pm 0.001$ & $0.023 \pm 0.001$ \\
\hline CHCU43684-6 & Gallo Cliff Dwelling & $1186 \pm 26$ & 0.709412 & 0.000011 & $133 \pm 1$ & $8.0 \pm 0.1$ & $0.055 \pm 0.001$ & $0.099 \pm 0.001$ \\
\hline CHCU43684-7 & Gallo Cliff Dwelling & $1184 \pm 29$ & 0.710244 & 0.000010 & $647 \pm 16$ & $12 \pm 0$ & $0.161 \pm 0.012$ & $0.064 \pm 0.002$ \\
\hline CHCU43684-8 & Gallo Cliff Dwelling & $1184 \pm 29$ & 0.709759 & 0.000011 & $101 \pm 4$ & $3.5 \pm 0.0$ & $0.027 \pm 0.001$ & $0.046 \pm 0.001$ \\
\hline CHCU43684-9 & Gallo Cliff Dwelling & $1190 \pm 28$ & 0.710010 & 0.000014 & $171 \pm 7$ & $3.1 \pm \mathbf{0 . 0}$ & $0.030 \pm 0.001$ & $0.026 \pm 0.000$ \\
\hline CHCU43684-10 & Gallo Cliff Dwelling & $1188 \pm 21$ & 0.709961 & 0.000014 & $102 \pm 2$ & $1.5 \pm 0.1$ & $0.040 \pm 0.000$ & $0.033 \pm 0.000$ \\
\hline CHCU43684-11 & Gallo Cliff Dwelling & $1188 \pm 21$ & 0.710270 & 0.000013 & $833 \pm 3$ & $21 \pm 0$ & $0.305 \pm 0.026$ & $1.43 \pm 0.03$ \\
\hline CHCU43684-12 & Gallo Cliff Dwelling & $1183 \pm 27$ & 0.710198 & 0.000010 & $593 \pm 16$ & $12 \pm 0$ & $0.135 \pm 0.001$ & $0.138 \pm 0.003$ \\
\hline CHCU43684-13 & Gallo Cliff Dwelling & $1184 \pm 24$ & 0.711580 & 0.000013 & $439 \pm 15$ & $4.2 \pm \mathbf{0 . 0}$ & $0.058 \pm 0.002$ & $0.032 \pm 0.001$ \\
\hline CHCU43684-14 & Gallo Cliff Dwelling & $1186 \pm 23$ & 0.711575 & 0.000015 & $328 \pm 3$ & $\mathbf{3 . 4} \pm \mathbf{0 . 0}$ & $0.049 \pm 0.002$ & $0.063 \pm 0.003$ \\
\hline CHCU43684-15 & Gallo Cliff Dwelling & $1184 \pm 24$ & 0.710143 & 0.000015 & $114 \pm 0$ & $3.5 \pm 0.0$ & $0.034 \pm 0.000$ & $0.050 \pm 0.000$ \\
\hline CHCU43684-16 & Gallo Cliff Dwelling & $1182 \pm 27$ & 0.710094 & 0.000013 & $187 \pm 2$ & $\mathbf{3 . 9} \pm \mathbf{0 . 0}$ & $0.036 \pm 0.000$ & $0.025 \pm 0.001$ \\
\hline CHCU57-1 & BC 236 & $1201 \pm 25$ & 0.710165 & 0.000014 & $459 \pm 17$ & $8.1 \pm 0.2$ & $0.117 \pm 0.000$ & $0.130 \pm 0.002$ \\
\hline
\end{tabular}

Bold ${ }^{87} \mathrm{Sr} /{ }^{86} \mathrm{Sr}$ values indicate samples with $\mathrm{Sr} \leq 5.5 \mu \mathrm{g} / \mathrm{g}$.

Bold and italicized ${ }^{87} \mathrm{Sr} /{ }^{86} \mathrm{Sr}$ values indicate samples with $\mathrm{Sr}>5.5$ and $\leq 12 \mu \mathrm{g} / \mathrm{g}$.

Pueblo Bonito cob dates taken from Cordell et al. (2008).

have previously shown to partition systematically from the soil water to the cob (Benson et al., 2008). We used the data obtained in the experiment to construct residual metal-pair ratios for each of the three cobs during the first hour of cob submergence (Fig. 9). The data indicated that cob submergence for $\leq 5 \mathrm{~min}$ has little effect on the metal-pair ratios of interest and that $\mathrm{Ba} / \mathrm{Sr}$ values are stable for at least $20 \mathrm{~min}$. Thus, we concluded that a few minutes of rinsing to remove attached sediment will not substantially alter the $\mathrm{Ba} / \mathrm{Mn}$, $\mathrm{Ba} / \mathrm{Sr}, \mathrm{Ca} / \mathrm{Sr}$, and $\mathrm{K} / \mathrm{Rb}$ metal-pair ratios. However, the sequence of steps involving the introduction of $\mathrm{HCl}$ and $\mathrm{HF}$ to dissolve contaminant mineral particles and the multiple rinses used to eliminate the acids from the sample result in the nonstoichiometric loss of metals in unburned cobs.

The fact that burned archaeological cobs retain sufficient organically bound $\mathrm{Sr}$ for ${ }^{87} \mathrm{Sr} /{ }^{86} \mathrm{Sr}$ analysis is probably due to the fact that maize contains large amounts of starch, cellulose, and sugars, which char upon roasting to activated carbon and charcoal. These materials are coated with lignin and lipid breakdown products which are excellent scavengers for trace metals. In addition, the metal-organic bond strengths of burned cobs are much stronger than the weak ion-exchange sites that characterize unburned cobs.

\subsection{Soil sampling}

In our studies, we sought to sample soils in floodplain and alluvial fan settings that were thought to have agricultural potential. In general, we sought field areas that were relatively rich in plants with loamy soils and that appeared "greener" than other areas. We also sampled sites that were proximate to great house communities.

Over time we gradually increased the number soil collection sites (Fig. 1). We initially confined our sampling to Chaco Canyon (Fig. 2), the base of the Chuskas, and the Totah area (Benson et al., 2003). However, as time progressed and as we obtained more archaeological cobs from the post-Chaco era, we collected soil samples from potential field systems located far from the Chaco core (Benson et al., 2006b). In Benson et al. (2009) we expanded our research to include a total of 178 soil sites found within 14 

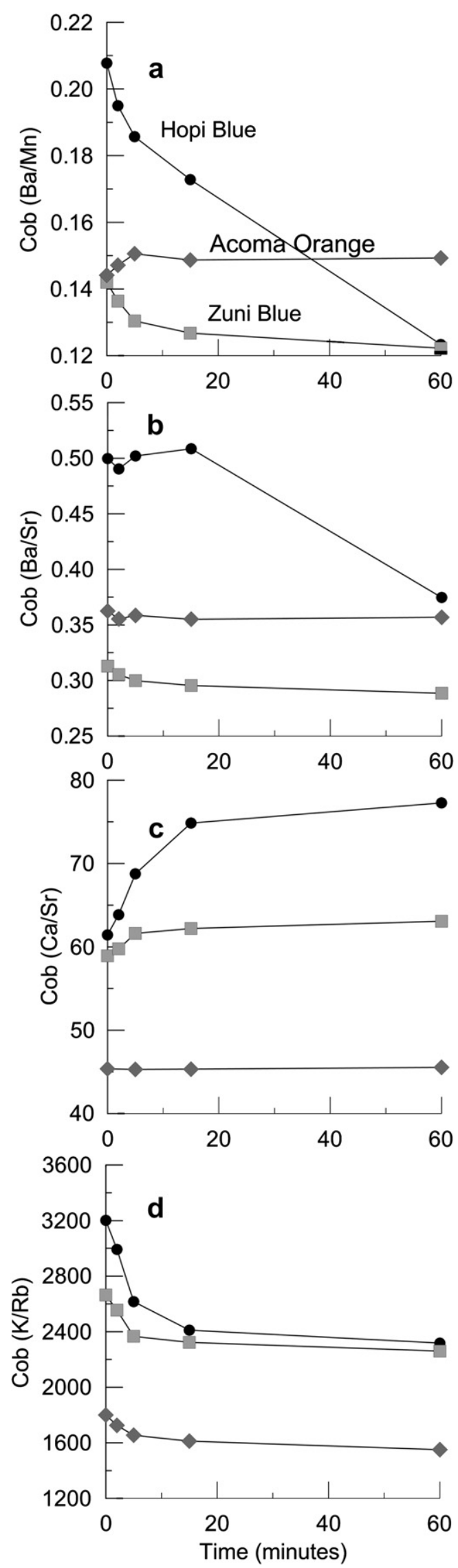

Fig. 9. Metal-pair ratios with time for three cob types submerged in deionized water. Hopi Blue cobs denoted by solid circles, Acoma Orange cobs denoted by solid diamonds, and Zuni Blue cobs denoted by solid squares. archaeological regions in the Southern Colorado Plateau region (Fig. 1); and in Benson (2010), 10 soils were collected from each of three field areas (Bear Canyon, Nutria, and Pescado) within the Zuni Reservation (Fig. 10). Intensive sampling of the Zuni area occurred in response to our studies of cobs grown after A.D. 1130, a time when Chacoans hypothesized to have migrated to the Zuni area (Kintigh et al., 2004) may have been supplying Canyon dwellers with Zuni maize.

Sr-isotope and trace-metal data for most of the soils can be found in Supplementary Tables 1 and 2 in Benson et al. (2009); Srisotope values of Zuni soils are listed in Table 3 in Benson (2010). Srisotope and trace metal analyses were performed on 11 surfacewater samples collected from Chaco Canyon, 12 surface-water samples collected from the perennial San Juan River system, and three surface-water samples collected from the Chuska slope (Supplementary Table 5 in Benson et al., 2009).

Eight bedrock samples were collected from the Chaco Canyon, Aztec Ruins, and Salmon Ruins areas. The ${ }^{87} \mathrm{Sr} /{ }^{86} \mathrm{Sr}$ data from these samples suggested that, for the most part, the biologically available $\mathrm{Sr}$ in study area soil waters was not coming from bedrock, but instead was coming from windblown calcium carbonate that had accumulated in the soil zone.

\section{Comparison of ${ }^{87} \mathrm{Sr} /{ }^{86} \mathrm{Sr}$ ratios of archaeological cobs with ${ }^{87} \mathrm{Sr} /{ }^{86} \mathrm{Sr}$ ratios of synthetic soil waters from fourteen archaeological regions}

Unfortunately, many of the early archaeologists that excavated in Chaco Canyon did not consider maize remains of great importance; therefore, not many cobs from Chaco Canyon great house contexts were archived. Given the status of existing collections, there will probably never be a sufficient number of archaeological cobs to clearly define where maize was grown between A.D. 860 and A.D. 1300. In addition, these cobs are invariably mineralcontaminated. The pervasiveness of this contamination was not apparent when we began our research, and initially we attempted

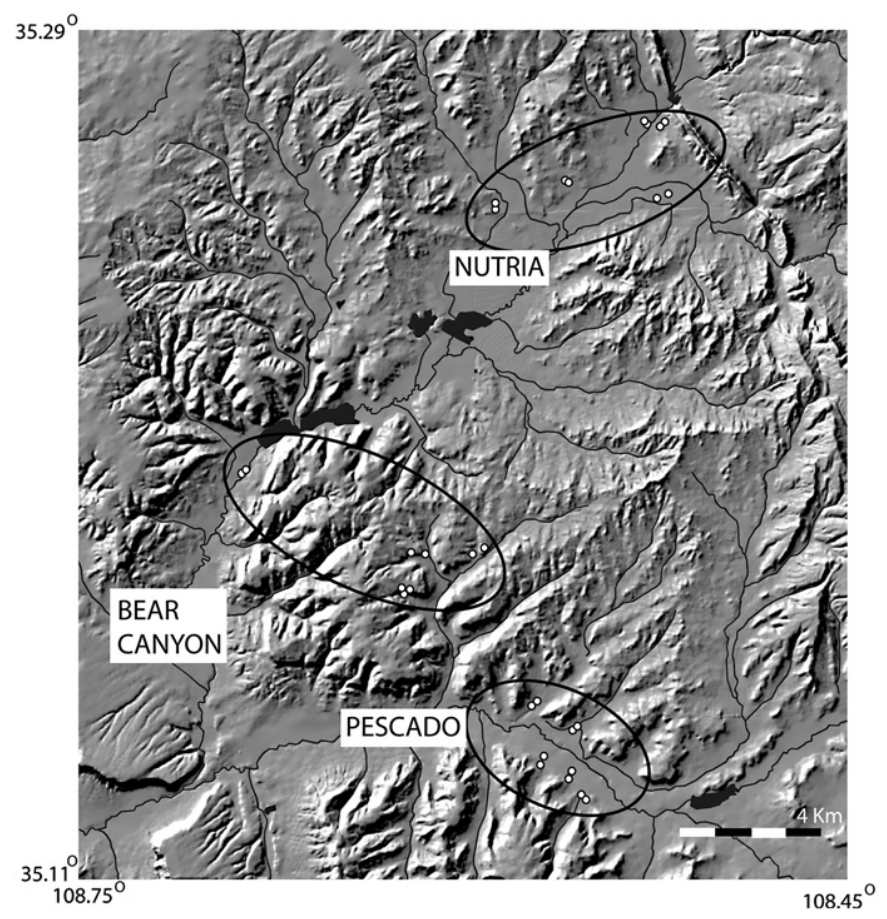

Fig. 10. Locations of soil sampling sites in the Zuni region of New Mexico. 
to clean the archaeological cobs by the simple physical removal of the outer surface (cupules) of the cob and any visible contaminant.

One measure of the chemical composition of clean unburned cobs comes from our analysis of 100 Southwestern Native American cobs from five landraces grown out at NMSU's Agricultural Science Center. These cobs had Al values ranging from 1.4 to $17 \mu \mathrm{g} / \mathrm{g}$ with a mean value of $4.9 \pm 4.4 \mu \mathrm{g} / \mathrm{g}$. Sr values ranged from 0.7 to $4.0 \mu \mathrm{g} / \mathrm{g}$ with a mean value of $1.5 \pm 0.6 \mu \mathrm{g} / \mathrm{g}$ and Ca values ranged from 22 to $157 \mu \mathrm{g} / \mathrm{g}$ with a mean value of $68 \pm 36 \mu \mathrm{g} / \mathrm{g}$ (Benson et al., 2008).

Of the 41 non-Navajo-age unburned archaeological cobs that we were able to obtain, 31 were from Chaco Canyon contexts and 10 were from Aztec Ruins with 16 of the Chaco cobs coming from Gallo Cliff Dwelling, a small building that was constructed and occupied after the collapse of Chaco (Benson et al., 2003, 2009) (Table 2). None of the cob Al values and only one Ca value (Table 2) falls within the range of the modern Southwestern Native American cobs, suggesting that all have been the archaeological cobs have been contaminated to some degree. However, 11 of the archaeological cobs have $\mathrm{Sr}$ concentrations $\leq 4.2 \mu \mathrm{g} / \mathrm{g}$, indicating that contaminants probably did not contribute additional $\mathrm{Sr}$ to these cobs (Table 2). It should be noted that different cob types grown in different soils may have different trace metal concentrations; for example, $\mathrm{Al}$ in four modern store bought cobs was found to range from 3 to $28 \mu \mathrm{g} / \mathrm{g}$ (H.E. Taylor, unpublished data).

One of the lessons learned from our studies of burned cobs was that the greater the degree of contamination (in some cases signaled by the concentration of $\mathrm{Al}$ ), the greater the ${ }^{87} \mathrm{Sr} /{ }^{86} \mathrm{Sr}$ ratio (Figs. 7 and 8). Therefore, one might assume that for sites in addition to Salmon Ruins, cobs with slightly elevated Al concentrations may exhibit slightly elevated ${ }^{87} \mathrm{Sr} /{ }^{86} \mathrm{Sr}$ ratios. In addition, nine of 10 burned Aztec cobs, subjected to our cleaning procedure (Benson et al., 2010), produced a pooled mean ${ }^{87} \mathrm{Sr} /{ }^{86} \mathrm{Sr}$ ratio of $0.70963 \pm 0.00004$, indicating that, in this case, cobs with $\mathrm{Sr}$ values $\leq 85 \mu \mathrm{g} / \mathrm{g}$ often yield reliable ${ }^{87} \mathrm{Sr} /{ }^{86} \mathrm{Sr}$ values.

For our ${ }^{87} \mathrm{Sr} /{ }^{86} \mathrm{Sr}$ cob:soil-water comparison, we split our cobs into three age categories: undated cobs from Aztec Ruins that are thought to have been grown after A.D. 1100 (the time of initial construction of Aztec Ruins complex) (Brown et al., 2008); cobs from Chaco Canyon that predate A.D. 1130 (before the collapse of Chaco); and cobs from Chaco Canyon that postdate A.D. 1130 (after the collapse of Chaco) (Table 2). In addition, we split each of the cob age categories into two $\mathrm{Sr}$ concentration groups: 17 cobs with $\mathrm{Sr}$ values $\leq 5.5 \mu \mathrm{g} / \mathrm{g}$ and 12 cobs with $\mathrm{Sr}$ values ranging from 6.8 to $12 \mu \mathrm{g} / \mathrm{g}$.

\section{1. ${ }^{87} \mathrm{Sr} /{ }^{86} \mathrm{Sr}$ ratios of cobs from Aztec Ruins}

One of the reasons we studied cobs from Aztec Ruins was because we thought it highly probable that the archaeological cobs had been grown on the alluvial fan on which the Aztec complex is situated and/or along the nearby Animas River floodplain. Therefore, the expectation was that the ${ }^{87} \mathrm{Sr} /{ }^{86} \mathrm{Sr}$ of the Aztec cobs would fall within the ${ }^{87} \mathrm{Sr} /{ }^{86} \mathrm{Sr}$ ratios of the Aztec soils. In Fig. 11, individual Aztec cob ${ }^{87} \mathrm{Sr} /{ }^{86} \mathrm{Sr}$ ratios are plotted against ${ }^{87} \mathrm{Sr} /{ }^{86} \mathrm{Sr}$ box-andwhisker plots for the surrounding Mesa Verde-McElmo Dome (MVMD), Dinetah (DI), Totah (TO), and Northwestern San Juan Basin (NWSJ) areas (Fig. 1). The Totah area encompasses soil sites near Salmon Ruins, Aztec Ruins, and along the Animas and La Plata Rivers (Fig. 1).

The Aztec Ruins cobs have ${ }^{87} \mathrm{Sr} /{ }^{86} \mathrm{Sr}$ ratios that, to some extent, overlap synthetic soil waters from both the Mesa Verde-McElmo Dome and Totah areas (Fig. 11). Two samples of Animas River water collected downstream (at Farmington, New Mexico) from the Aztec site have ${ }^{87} \mathrm{Sr} /{ }^{86} \mathrm{Sr}$ ratios of $0.70950 \pm 0.00001$ and $0.70966 \pm 0.00002$ (Supplementary Table 5 in Benson et al., 2009),

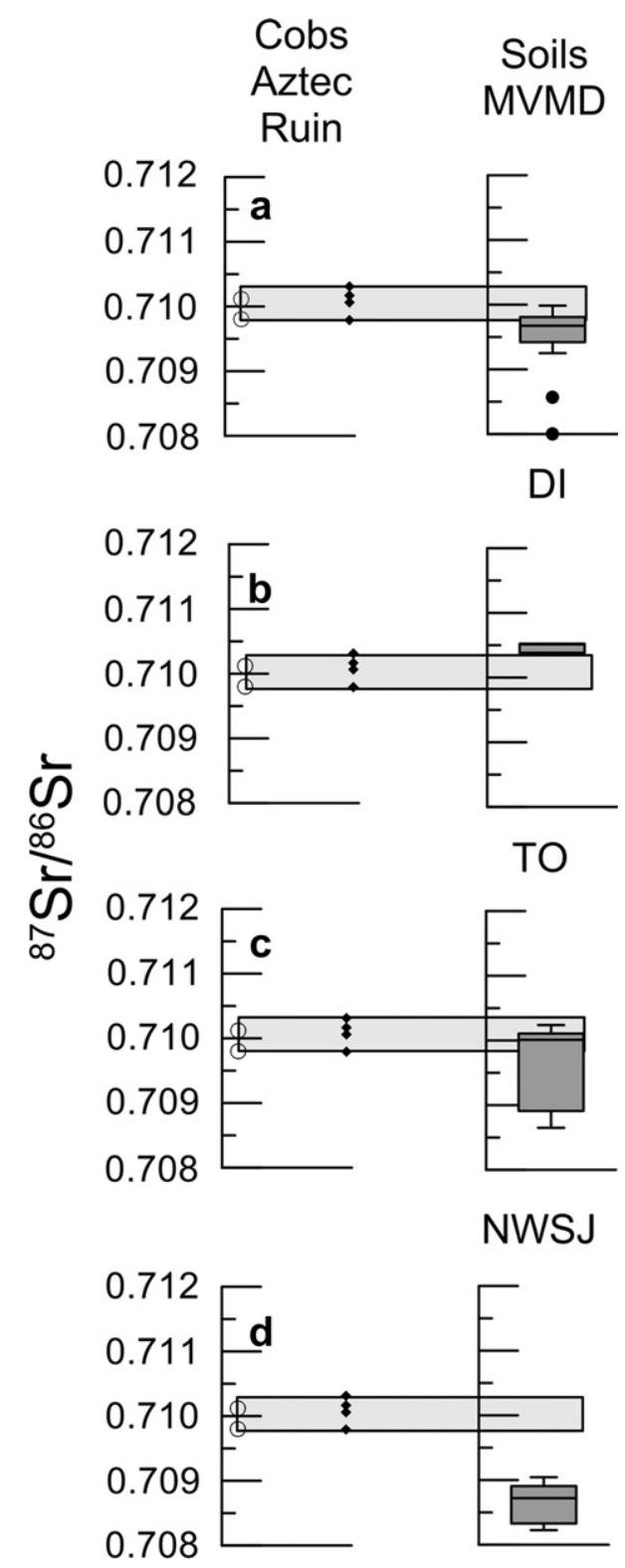

Fig. 11. Comparison of Aztec Ruins cob ${ }^{87} \mathrm{Sr} /{ }^{86} \mathrm{Sr}$ ratios with the ${ }^{87} \mathrm{Sr} /{ }^{86} \mathrm{Sr}$ ratios of soils (box-and-whisker plots) in surrounding archaeological regions. MVMD = Mesa VerdeMcElmo Dome; Di = Dinetah; TO = Totah, and NWSJ = Northwestern San Juan Basin (see Fig. 1). The first and third quartiles are at the lower and upper ends of the box, the median is indicated with a horizontal line in the interior of the box, and the maximum and minimum are represented by bars at the ends of the whiskers.

which are slightly smaller than the range of $\mathrm{cob}{ }^{87} \mathrm{Sr} /{ }^{86} \mathrm{Sr}$ values. However, two water samples collected from the San Juan River slightly upstream from the Salmon Ruins site had ${ }^{87} \mathrm{Sr} /{ }^{86} \mathrm{Sr}$ ratios of $0.71029 \pm 0.00001$ and $0.71038 \pm 0.00002$ (Supplementary Table 5 in Benson et al., 2009) which fall within the range of Aztec cob ${ }^{87} \mathrm{Sr} /{ }^{86} \mathrm{Sr}$ values.

4.2. ${ }^{87} \mathrm{Sr} /{ }^{86} \mathrm{Sr}$ ratios of cobs from Chaco Canyon that predate A.D. 1130

Relatively clean cobs from Pueblo Bonito (6 cobs) and Gallo Cliff Dwelling $(1 \mathrm{cob})$ that predate A.D. 1130 have ${ }^{87} \mathrm{Sr} /{ }^{86} \mathrm{Sr}$ ratios that tend to match Chaco Canyon side valley (CSV), upper Rio Chaco (URC), Zuni Nutria (ZN), Mesa Verde-McElmo Dome (MVMD), Totah 


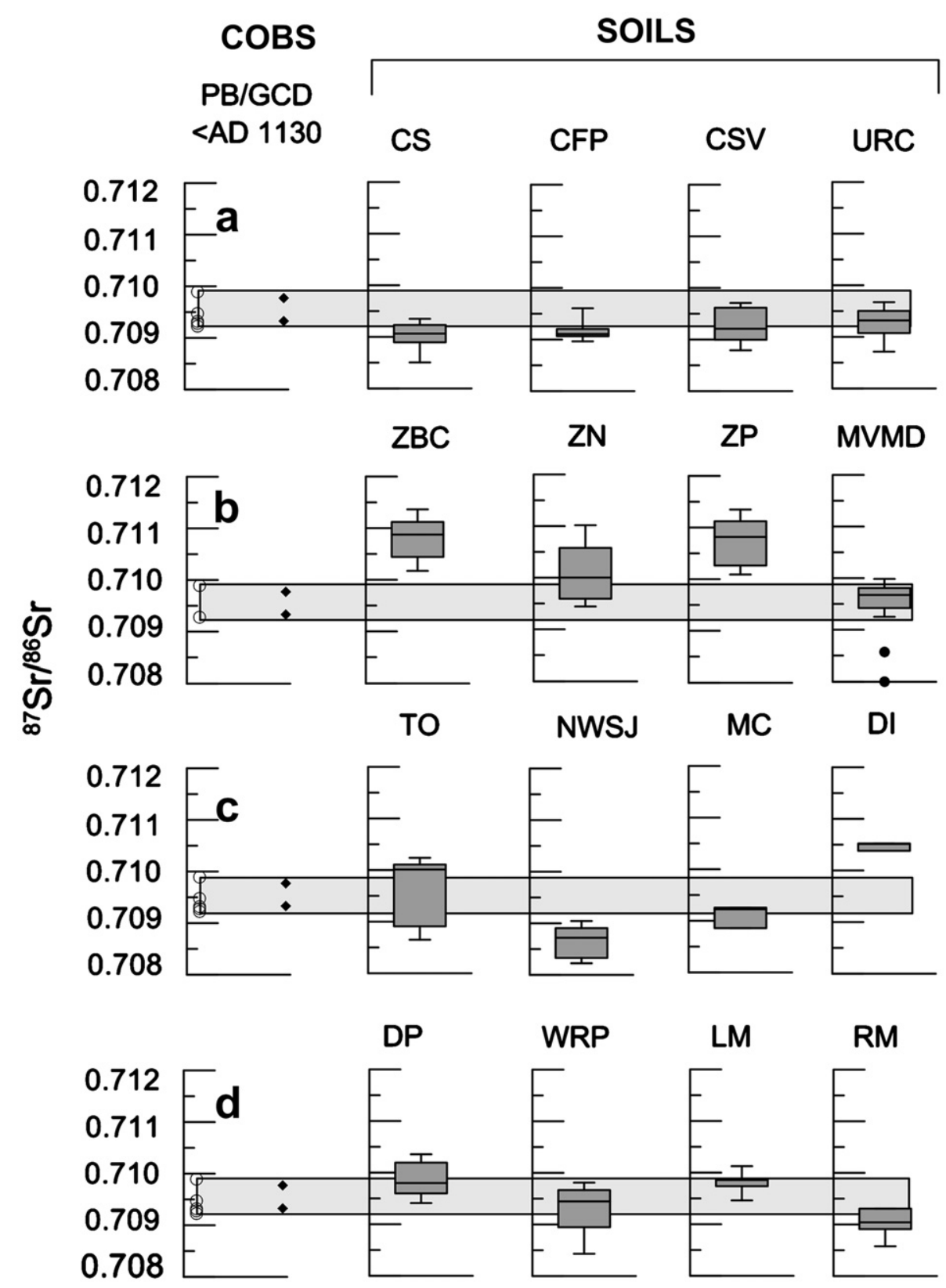

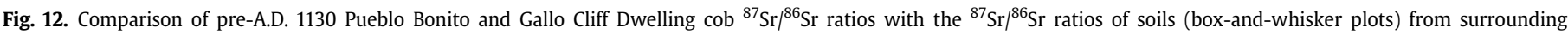

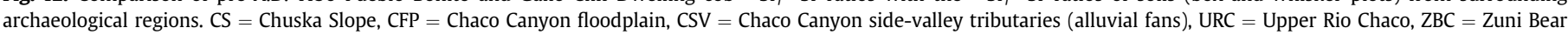

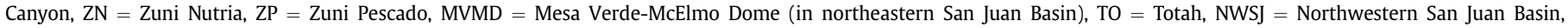

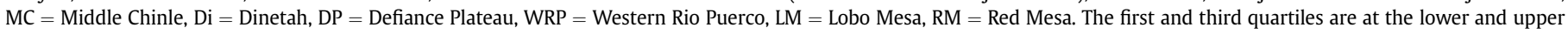

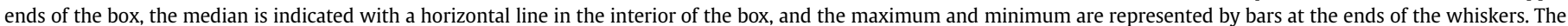
black dots in the Mesa Verde-McElmo Dome whisker plot represent outliers in the data set.

(TO), Defiance Plateau (DP), and Western Rio Puerco (WRP) ${ }^{87} \mathrm{Sr} /{ }^{86} \mathrm{Sr}$ values (Figs. 1 and 12). The cob ${ }^{87} \mathrm{Sr} /{ }^{86} \mathrm{Sr}$ ratios also have some overlap with five other archaeological region soils (Figs. 1 and 12).

${ }^{87} \mathrm{Sr} /{ }^{86} \mathrm{Sr}$ ratios from Chaco, Fajada, and Gallo wash-water systems ( 7 samples), within the Canyon valley floor, range from $0.70904 \pm 0.00001$ and $0.70941 \pm 0.00003$ and ${ }^{87} \mathrm{Sr} /{ }^{86} \mathrm{Sr}$ ratios from Chaco Canyon side-tributary systems (4 samples) range from $0.70969 \pm 0.00002$ and $0.70991 \pm 0.00002$ (Supplementary Table 5 in Benson et al., 2009). Both the side-tributary and valley-floor water ${ }^{87} \mathrm{Sr} /{ }^{86} \mathrm{Sr}$ ratios match some of the $\mathrm{cob}{ }^{87} \mathrm{Sr} /{ }^{86} \mathrm{Sr}$ values (Fig. 12).

Although other sites cannot be ruled out, the ${ }^{87} \mathrm{Sr} /{ }^{86} \mathrm{Sr}$ data are consistent with the hypothesis that the Pueblo Bonito and Chetro Ketl cobs came from the Rio Chaco corridor. Chaco Canyon side- valley sites whose ${ }^{87} \mathrm{Sr} /{ }^{86} \mathrm{Sr}$ values overlap the Pueblo Bonito and Chetro Ketl cob ${ }^{87} \mathrm{Sr} /{ }^{86} \mathrm{Sr}$ values (0.70922-0.70989) include Gallo Wash (one sample) and South Gap (three samples). On the other hand, 25 Upper Rio Chaco soils from 13 archaeological sites had ${ }^{87} \mathrm{Sr} /{ }^{86} \mathrm{Sr}$ values within the cob ${ }^{87} \mathrm{Sr} /{ }^{86} \mathrm{Sr}$ range (compare clean cob ${ }^{87} \mathrm{Sr} /{ }^{86} \mathrm{Sr}$ values from Table 2 with soil ${ }^{87} \mathrm{Sr} /{ }^{86} \mathrm{Sr}$ values in Supplementary Table 1 in Benson, 2010).

\section{3. ${ }^{87} \mathrm{Sr} /{ }^{86} \mathrm{Sr}$ ratios of cobs from Chaco Canyon that postdate A.D. 1130}

There are 10 clean and five relatively clean cobs from site BC 236 and Gallo Cliff Dwelling that postdate A.D. 1130 (Table 2). All but 
one cob were collected from Gallo Cliff Dwelling. ${ }^{87} \mathrm{Sr} /{ }^{86} \mathrm{Sr}$ ratios of the clean cobs match ranges in ${ }^{87} \mathrm{Sr} /{ }^{86} \mathrm{Sr}$ values from Zuni Nutria (ZN), Mesa Verde-McElmo Dome (MVMD), Totah (TO), Defiance Plateau (DP), and Lobo Mesa (LM) soils (Fig. 13). The latter two sites can be rejected because they were unpopulated at this time (Fowler and Stein, 1992). The ${ }^{87} \mathrm{Sr} /{ }^{86} \mathrm{Sr}$ ratios $(0.70969 \pm 0.00002$ and $0.709991 \pm 0.00002)$ of side-tributary Chaco Canyon surface waters overlap some of the cob ${ }^{87} \mathrm{Sr} /{ }^{86} \mathrm{Sr}$ values (Fig. 13). Thus, the ${ }^{87} \mathrm{Sr} /{ }^{86} \mathrm{Sr}$ cob data best match ${ }^{87} \mathrm{Sr} /{ }^{86} \mathrm{Sr}$ soil data from the area in and near the Totah region as well as part of the Zuni region to which people from Chaco migrated during the early A.D. 1100s.

\section{Problems with the application of trace-metal ratios to source archaeological cobs}

As discussed above, Benson (2010) and Benson et al. (2010) demonstrated that any mineral-contaminant cleaning procedure which employed immersing a cob in an aqueous solution for more than a few minutes resulted in the wholesale leaching of metals

\section{COBS}

SOILS

\section{GCD/BC236 \\ $>$ A.D. 1130}
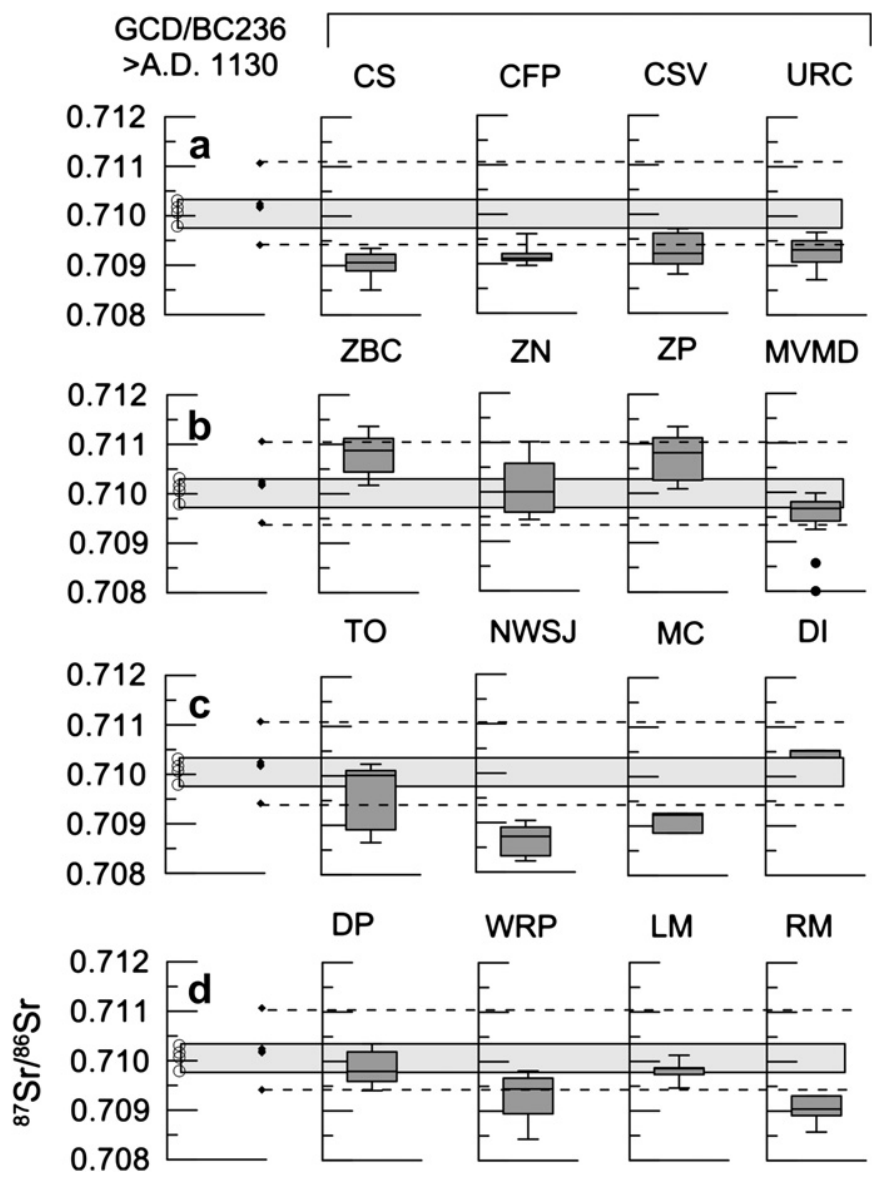

Fig. 13. Comparison of post-A.D. 1130 BC 236 and Gallo Cliff Dwelling cob ${ }^{87} \mathrm{Sr} /{ }^{86} \mathrm{Sr}$ ratios with the ${ }^{87} \mathrm{Sr} /{ }^{86} \mathrm{Sr}$ ratios of soils (box-and-whisker plots) from surrounding archaeological regions. CS = Chuska Slope, CFP = Chaco Canyon floodplain, $\mathrm{CSV}=$ Chaco Canyon side-valley tributaries (alluvial fans), URC = Upper Rio Chaco, ZBC = Zuni Bear Canyon, ZN = Zuni Nutria, ZP = Zuni Pescado, MVMD = Mesa VerdeMcElmo Dome (in northeastern San Juan Basin), TO = Totah, NWSJ = Northwestern San Juan Basin, MC = Middle Chinle, Di $=$ Dinetah, DP $=$ Defiance Plateau, WRP $=$ Western Rio Puerco, LM = Lobo Mesa, RM = Red Mesa. The first and third quartiles are at the lower and upper ends of the box, the median is indicated with a horizontal line in the interior of the box, and the maximum and minimum are represented by bars at the ends of the whiskers. The black dots in the Mesa VerdeMcElmo Dome whisker plot represent outliers in the data.
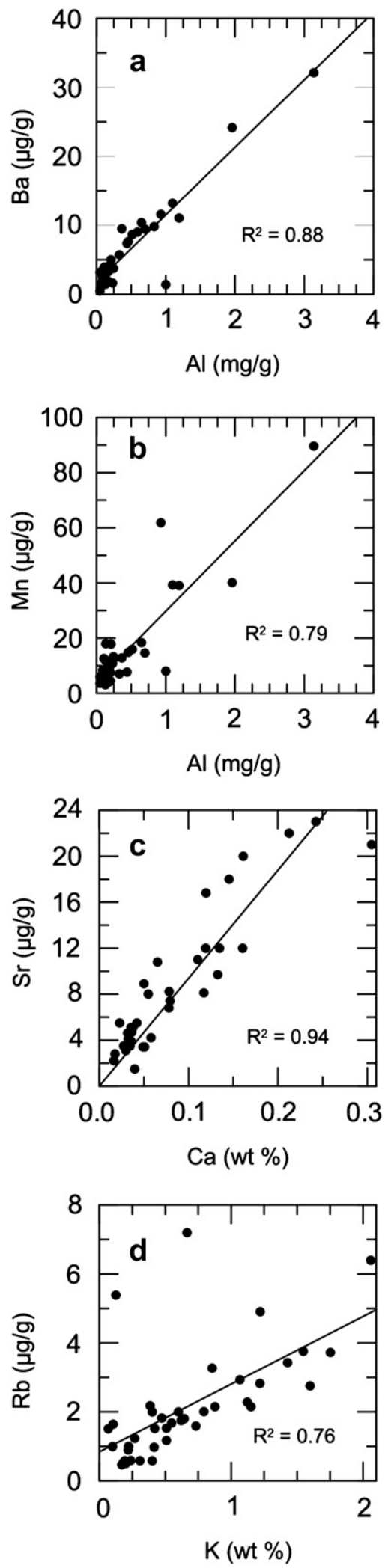

Fig. 14. Trace-metal plots for archaeological cobs listed in Table 2: a, Ba vs. Al, b, Mn vs. $\mathrm{Al}, \mathrm{c}, \mathrm{Sr}$ vs. Ca, d, Rb vs. K. Samples with $\mathrm{Sr}$ values $>24 \mu \mathrm{g} / \mathrm{g}$ have been clipped from the plot c; linear regression in d done for samples with $\mathrm{Rb}<24 \mu \mathrm{g} / \mathrm{g}$. 
from the cobs. In addition, Benson et al. (2009) found that most cobs whose cupules and other surficial materials had been physically removed remained contaminated with some mineral matter. For example, the calculation of cob $\mathrm{Ba} / \mathrm{Mn}$ ratios from synthetic soil-water ratios, using Equation (1), resulted in cob-derived soilwater $\mathrm{Ba} / \mathrm{Mn}$ values of $7.0 \pm 3.6$ that were completely outside the range of the measured synthetic soil-water $\mathrm{Ba} / \mathrm{Mn}$ ratios $(0.53 \pm 0.47)$.

Both $\mathrm{Ba}$ and $\mathrm{Mn}$ are highly correlated with $\mathrm{Al}$, especially $\mathrm{Ba}$ (Fig. 14a and b), also indicating that they reflect the presence of an Al-bearing mineral contaminant. The $\mathrm{Sr}$ values of cobs were also highly correlated with their Ca values, suggesting the presence of either a calcite $\left(\mathrm{CaCO}_{3}\right)$ or a gypsum $\left(\mathrm{CaSO}_{4}\right)$ (Fig. 14c) contaminant. These relations, therefore, obviate the application of $\mathrm{Ba} / \mathrm{Sr}, \mathrm{Ba} / \mathrm{Mn}$, and $\mathrm{Ca} / \mathrm{Sr}$ trace-metal distribution coefficients for the sourcing of archaeological cobs listed in Table 2.

Benson et al. (2009) showed that $\mathrm{K}$ and $\mathrm{Rb}$ in the cobs listed in Table 2 were not correlated with $\mathrm{Al}$ when its concentration was $<250 \mu \mathrm{g} / \mathrm{g}$. Therefore, they argued that the $\mathrm{K} / \mathrm{Rb}$ trace-metal pair could be used to source cobs when cob Al values $<250 \mu \mathrm{g} / \mathrm{g}$. However, if one plots $\mathrm{Rb}$ versus $\mathrm{K}$, these metals are well correlated for $\mathrm{Rb}$ values $<4 \mu \mathrm{g} / \mathrm{g}$ (Fig. 14d), indicating the presence of a mineral contaminant such as a K-mica. Therefore, we also reject the application of the $\mathrm{K} / \mathrm{Rb}$ metal pair in the sourcing of cobs listed in Table 2 . $\mathrm{K}$ and $\mathrm{Rb}$ values of cobs can be found in Supplementary Tables 3 and 4 of Benson et al. (2009).

\section{A failed attempt to apply $\mathrm{Pb}$ isotopes to the sourcing of archaeological cobs}

An attempt was made to apply Pb isotopes $\left({ }^{208} \mathrm{~Pb},{ }^{207} \mathrm{~Pb},{ }^{206} \mathrm{~Pb}\right.$, ${ }^{204} \mathrm{~Pb}$ ) to the sourcing of archaeological cobs in the same manner that $\mathrm{Sr}$ isotopes were applied. It was thought that the Pb-isotope content of soils from the various archaeological regions might differ to the extent that their $\mathrm{Pb}$-isotope values might provide a further means of distinguishing maize source areas.
In Table 3 are listed $\mathrm{Pb}$ and $\mathrm{Pb}$-isotope values for cobs and synthetic soil waters from the Totah and Chaco Canyon/Chuska Slope areas. One problem, indicated by cob $\mathrm{Pb}$ values, is that a single cob does not generally contain sufficient $\mathrm{Pb}$ for an isotopic analysis. In addition, clean modern Southwestern Native American cobs contain much less $\mathrm{Pb}(0.012 \pm 0.008 \mu \mathrm{g} / \mathrm{g}$ with a range of $0.003-0.023 \mu \mathrm{g} / \mathrm{g}$ ) than the archaeological cobs (Supplementary Table 1 in Benson et al., 2008). Obviously, most of the cobs listed in Table 3 are $\mathrm{Pb}$ contaminated. That uncontaminated cobs contain little $\mathrm{Pb}$ is not surprising given that heavy metals are generally rejected by plants (see, for example, Brennan and Shelley, 1999).

The $\mathrm{Pb}$-isotope ratios of the synthetic soil waters, cobs, and one Animas River sample have been plotted in Fig. 15. The Pb-isotope ratios of soil waters from different areas do not plot in distinctly separate areas; for example, the Aztec Ruins (AR) soil waters overlap the Chaco Canyon (CC) soil waters in ${ }^{207} \mathrm{~Pb} /{ }^{204} \mathrm{~Pb}-{ }^{206}$ $\mathrm{Pb} /{ }^{204} \mathrm{~Pb}$ space (Fig. 15a) and the Chuska Slope soil waters straddle the Salmon Ruin soil waters in ${ }^{207} \mathrm{~Pb} /{ }^{204} \mathrm{~Pb}-{ }^{206} \mathrm{~Pb} /{ }^{204} \mathrm{~Pb}$ space (Fig. 15a) as well as in ${ }^{208} \mathrm{~Pb} /{ }^{204} \mathrm{~Pb}-{ }^{206} \mathrm{~Pb} /{ }^{204} \mathrm{~Pb}$ space (Fig. 15b). In addition, the $\mathrm{Pb}$-isotope ratios of the five cobs bear little relation to the $\mathrm{Pb}$-isotope ratios of the soil waters, indicating that $\mathrm{Pb}$ contamination of the archaeological cobs greatly affected their $\mathrm{Pb}-$ isotope ratios (Fig. 15).

\section{Field sampling strategies}

In Benson et al. (2003), soil sampling was done at multiple (2-3) depths within the rooting zone of maize $(\sim 1.5 \mathrm{~m})$. It was found that the ${ }^{87} \mathrm{Sr} /{ }^{86} \mathrm{Sr}$ ratios of the synthetic soil waters produced from these samples did not vary substantially $(<2$ digits in the fourth decimal place) with depth (Fig. 16). Therefore, in subsequent studies, prior to the Zuni study, only one soil sample was collected from each site (Benson, 2010). Zuni soil samples were taken not only to determine their ${ }^{87} \mathrm{Sr} /{ }^{86} \mathrm{Sr}$ synthetic soil-water ratios but also to determine their agricultural potential via measurements of nitrogen, carbon, $\mathrm{pH}$, etc. Therefore, four soil samples (each $225 \mathrm{~cm}^{3}$ in volume) from

Table 3

$\mathrm{Pb}$ and $\mathrm{Pb}$-isotope values for archaeological cobs and synthetic soil water.

\begin{tabular}{|c|c|c|c|c|c|c|c|c|c|}
\hline \multirow[t]{2}{*}{ Cob No. } & $\mathrm{Pb}$ conc & $\mathrm{Pb} 206 / 204$ & $\mathrm{~Pb} 207 / 204$ & $\mathrm{~Pb} 208 / 204$ & \multirow[t]{2}{*}{ Soil No. } & $\mathrm{Pb}$ conc & $\mathrm{Pb} 206 / 204$ & $\mathrm{~Pb} 207 / 204$ & $\mathrm{~Pb} 208 / 204$ \\
\hline & \multicolumn{4}{|l|}{$(\mu \mathrm{g} / \mathrm{g})$} & & \multicolumn{4}{|l|}{$(\mu \mathrm{g} / \mathrm{g})$} \\
\hline \multicolumn{5}{|c|}{ Archaeological Cobs } & \multicolumn{5}{|c|}{ Synthetic Soil Water } \\
\hline \multicolumn{5}{|l|}{ Aztec Ruins } & \multicolumn{5}{|l|}{ Aztec Ruins } \\
\hline AZRU 533A & 0.30 & 19.890 & 15.688 & 38.317 & AZR\#2 & 3.75 & 18.889 & 15.606 & 38.366 \\
\hline AZRU 533B & 0.04 & & & & AZR\#5 & 0.93 & 18.948 & 15.596 & 38.600 \\
\hline AZRU 943B & 0.04 & & & & AZR\#8 & 1.06 & 18.923 & 15.584 & 38.510 \\
\hline AZRU 1052 & 0.05 & 19.605 & 15.631 & 38.427 & Salmon Ruins & & & & \\
\hline AZRU 1057 & 0.09 & & & & SR\#3 & 0.37 & 19.361 & 15.641 & 39.426 \\
\hline AZRU 3853 & 0.02 & & & & SR\#6 & 1.10 & 19.281 & 15.625 & 39.390 \\
\hline AZRU 11091 & 0.20 & & & & SAL\#1 & 0.97 & 19.370 & 15.630 & 38.947 \\
\hline AZRU 9651 & 0.33 & 18.872 & 15.579 & 39.212 & SAL\#2 & 1.65 & 19.294 & 15.622 & 38.839 \\
\hline \multicolumn{5}{|l|}{ Pueblo Bonito } & \multicolumn{5}{|l|}{ Chuska Slope } \\
\hline $\mathrm{H} 242 / 244 \mathrm{~A}$ & 0.05 & 20.588 & 15.721 & 38.097 & TGHBM\#1 & 0.64 & 19.617 & 15.661 & 39.173 \\
\hline H242/244B & 0.11 & & & & TGHBM\#2 & 0.54 & 19.576 & 15.646 & 39.108 \\
\hline $\mathrm{H} 254 / 258 \mathrm{~A}$ & 0.13 & & & & TGHBM\#3 & 0.49 & 19.582 & 15.640 & 39.117 \\
\hline H254/258B & 0.02 & 18.587 & 15.509 & 37.990 & TGHBM\#4 & 0.33 & 19.007 & 15.598 & 38.756 \\
\hline $\mathrm{H} 254 / 258 \mathrm{C}$ & 0.07 & & & & TGHBM\#5 & 0.18 & 19.114 & 15.612 & 38.815 \\
\hline \multirow[t]{11}{*}{ H7673 } & 0.04 & & & & TGHBM\#6 & 0.26 & 19.034 & 15.609 & 38.816 \\
\hline & & & & & TGHBM\#7 & 0.46 & 19.109 & 15.601 & 38.775 \\
\hline & & & & & \multicolumn{5}{|l|}{ Chaco Canyon } \\
\hline & & & & & CC\#2 & 0.58 & 18.958 & 15.586 & 38.638 \\
\hline & & & & & PDA\#1 & 0.78 & 18.991 & 15.601 & 38.694 \\
\hline & & & & & CKF\#2 & 0.94 & 18.971 & 15.590 & 38.665 \\
\hline & & & & & CR\#2 & 0.73 & 18.986 & 15.591 & 38.682 \\
\hline & & & & & S10\#2 & 0.88 & 18.951 & 15.593 & 38.658 \\
\hline & & & & & WR\#1 & 0.27 & 18.936 & 15.589 & 38.659 \\
\hline & & & & & \multicolumn{5}{|c|}{ River Water $(\mathrm{Pb}$ in $\mu \mathrm{g} / \mathrm{L}$ ) } \\
\hline & & & & & Animas River & 0.01 & 18.534 & 15.503 & 37.897 \\
\hline
\end{tabular}


each Zuni site were collected at depths of $10-16,40-46,70-76$, and $100-106 \mathrm{~cm}$, air dried, and homogenized prior to isotopic analyses.

Because soil samples only yield ${ }^{87} \mathrm{Sr} /{ }^{86} \mathrm{Sr}$ ratios at a few points within a field, it was not apparent whether they were representative of the overall ${ }^{87} \mathrm{Sr} /{ }^{86} \mathrm{Sr}$ ratio. This was true even though an effort was made to collect from multiple sites within single field settings. To test the representativeness of the synthetic soil waters, we also measured the ${ }^{87} \mathrm{Sr} /{ }^{86} \mathrm{Sr}$ ratios of deer mice (Peromyscus maniculatus) from 9 fields within Chaco Canyon, one field alongside Escavada Wash, and two Upper Rio Chaco fields (Kin Klizhin and Kin Bineola) (Benson et al., 2008). P. maniculatus have home ranges 240-3000 $\mathrm{m}^{2}$ in area (Bunker, 2001) and they subsist chiefly on seeds, fruits, and insects.
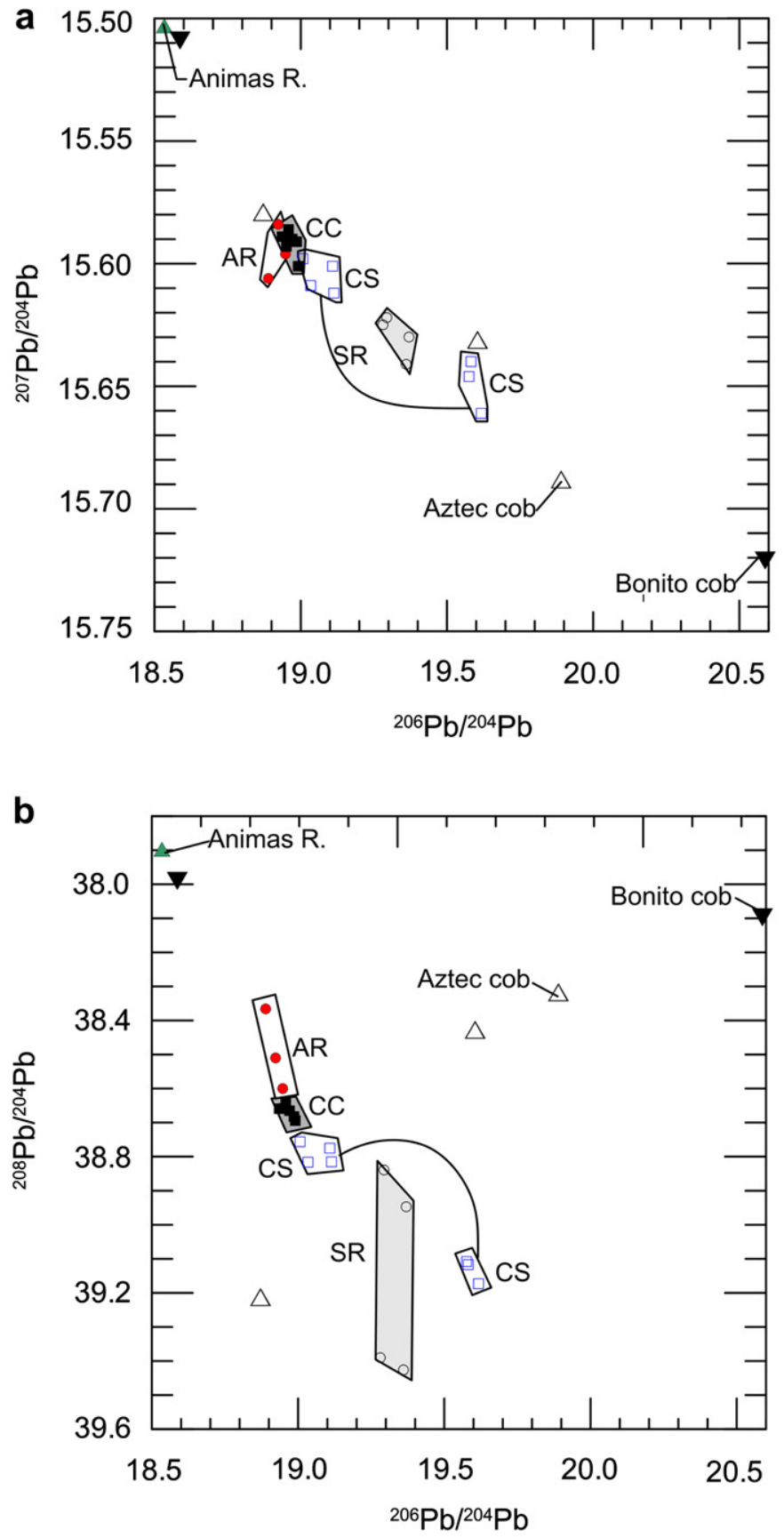

Fig. 15. Pb-isotope plots from selected study area soils and archaeological cobs: a, ${ }^{207} \mathrm{~Pb} /{ }^{204} \mathrm{~Pb}$ vs. ${ }^{206} \mathrm{~Pb} /{ }^{204} \mathrm{~Pb}$ plot b, ${ }^{208} \mathrm{~Pb} /{ }^{204} \mathrm{~Pb}$ vs. ${ }^{206} \mathrm{~Pb} /{ }^{204} \mathrm{~Pb}$ plot.

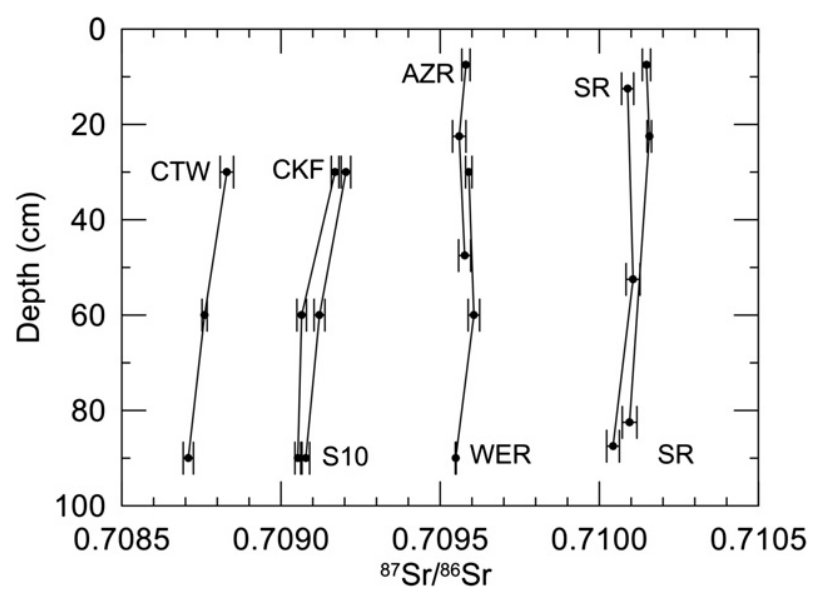

Fig. 16. Sr-isotope values with depth at Captain Toms Wash (CTW), Chetro Ketl Field (CKF), field S10 (S10), Aztec Ruin (AZR), Weritos Rincon (WER), and Salmon Ruin (SR).

The data obtained in this study indicated that mice ${ }^{87} \mathrm{Sr} /{ }^{86} \mathrm{Sr}$ values were often greater (generally 1-4 digits in the fourth decimal place) than ${ }^{87} \mathrm{Sr} /{ }^{86} \mathrm{Sr}$ values of synthetic soil waters obtained from the same field. On one hand, the data suggest that soilwater ${ }^{87} \mathrm{Sr} /{ }^{86} \mathrm{Sr}$ values are not completely representative of fieldscale ${ }^{87} \mathrm{Sr} /{ }^{86} \mathrm{Sr}$ values; however, a closer examination of the data (Table 1 in Benson et al., 2008) indicates that near-surface synthetic soil waters had ${ }^{87} \mathrm{Sr} /{ }^{86} \mathrm{Sr}$ values similar to those obtained from the mice. This suggests that the mice were obtaining their $\mathrm{Sr}$ from plants that were shallowly rooted or that insects the mice consumed were extracting $\mathrm{Sr}$ from shallowly rooted plants. Thus, the biologically labile $\mathrm{Sr}$ from deeper soil samples may be more representative of that extracted by the roots of maize.

\section{Lessons learned}

What have we learned from our attempts to use heavy-metal isotopes and trace-metal ratios to source archaeological cobs?

1. First and foremost, the acquisition of clean cobs is paramount. Unfortunately, the contexts from which archaeological cobs are recovered usually permit contamination via construction rubble (for example stone and plaster) within which the cobs have persisted for the past millennium or so. In order to locate and remove contaminants from archaeological cobs, the following set of procedures is recommended. The outer surface of the cobs, including the cupules, should be removed with a titanium or ceramic knife. Next, the cob should be rinsed under a high-pressure jet of deionized water to remove contaminants that remain on the cob surface. The cob should then be immersed in a $10 \%$ high-purity $\mathrm{HCl}$ solution and ultrasonicated for 5-10 min. The cob should next be rinsed in DI water to remove residual acid and freeze dried. After drying, the cob should be cut in $<1-\mathrm{cm}$-size pieces and the pieces examined under an environmental scanning electron microscope (ESEM) equipped with an energy dispersive X-ray (EDX) detector for chemical analysis and X-ray mapping. Elements with atomic numbers $>10$ can be mapped; for example, one can scan for common rock-forming metals such as $\mathrm{Na}, \mathrm{Ca}, \mathrm{Mg}$, $\mathrm{Al}, \mathrm{Si}, \mathrm{Fe}$ as well as $\mathrm{Sr}, \mathrm{Pb}$, and $\mathrm{Mn}$. If contaminant-free pieces of cobs are documented, they can be subjected to isotopic and metals analysis after ashing, etc. Slightly contaminated pieces of cobs can be subjected to additional ultrasonification or highpressure rinsing steps. To ensure that the trace elements in the cobs are not being leached during their exposure to liquids, 
modern clean cobs should be subjected to the same procedures and their metal chemistry determined after each immersion or rinsing. The chemical evolution of the modern cobs over time should then be compared with their initial chemical composition to determine if metals are being lost and whether the loss is congruent or incongruent.

2. Given the relative "stickiness" of cation sites in burned cobs, the multi-acid cleaning procedure discussed above can be applied to such cobs; however, metals leach incongruently during this procedure, obviating the application of the tracemetal distribution coefficient approach.

3. If only ${ }^{87} \mathrm{Sr} /{ }^{86} \mathrm{Sr}$ is to be used to determine the location of potential agricultural field systems, it probably is best to combine several depth-integrated samples collected from individual fields. In addition, it may be more efficient to combine vegetation samples from a relatively large area. For example, it would be much quicker to combine and process 20 rabbitbrush (Chrysothamnus nauseosus) samples from a 10-acre area than it would be to integrate and process 2050 -cm-deep soil samples.

4. It should not be assumed that biologically labile $\mathrm{Sr}$ contained in soil water has its origin in the underlying bedrock. In the American Southwest, most of the biologically available $\mathrm{Sr}$ is probably obtained from windblown calcium carbonate.

5. The greater the number of potential agricultural fields sampled, the greater the number of potential matches between soilwater ${ }^{87} \mathrm{Sr} /{ }^{86} \mathrm{Sr}$ and $\mathrm{cob}{ }^{87} \mathrm{Sr} /{ }^{86} \mathrm{Sr}$ ratios. This implies that other chemical methods must often be employed to link archaeological cobs to their source fields or that one may have to default to other lines of evidence.

6. The application of ${ }^{87} \mathrm{Sr} /{ }^{86} \mathrm{Sr}$ ratios of surface-water samples to maize sourcing is limited to those situations in which the $\mathrm{Sr}$ concentration of the surface-water contribution to the $\mathrm{Sr}$ concentration of soil water is substantial. Such a situation may occur within fields occupying floodplains whose sediments contain little leachable Sr.

7. $\mathrm{Sr}$ isotopes can be applied to other organic materials, including burned structural materials common to abandoned archaeological structures found in the American Southwest; e.g., $\mathrm{Sr}$ isotopes have previously been used to source willow and tule textiles created by prehistoric Native Americans (Benson et al., 2006a) that occupied the Great Basin and such techniques could be applied to other textiles found in Southwestern archaeological settings.

8. Understanding the flow of foodstuffs to Chaco Canyon between A.D. 850 and A.D. 1300 is very dependent on the number of samples analyzed and their distribution over the 450-yr time span. Until more clean datable cobs become available for analysis, our attempts to understand the change in maize source areas over time will remain severely limited.

\section{Where did the cobs come from that were found at Aztec Ruin and Chaco Canyon?}

Sr-isotope data indicate that archaeological cobs from Aztec Ruins came from either the Mesa Verde-McElmo Dome or Totah areas. Pueblo Bonito and Chetro Ketl cobs, from Chaco Canyon that predate A.D. 1130, probably came from the Rio Chaco corridor. Only a few soil samples from side-valley tributaries within Chaco Canyon have ${ }^{87} \mathrm{Sr} /{ }^{86} \mathrm{Sr}$ ratios that match pre-A.D. 1130 cob values, whereas numerous soil samples from several sites both upstream and downstream of the Canyon match pre-A.D. 1130 cob values. Cobs from Chaco Canyon, that postdate A.D. 1130, came from either the Totah or Zuni areas, both of which probably had preexisting cultural ties to Chaco. These data are consistent with the hypotheses that Chaco was materially and culturally linked to great houses and villages along the Chaco Corridor prior to its demise at $\sim$ A.D. 1130 and that, after A.D. 1180, people in the Zuni or Totah areas continued to materially support a residual population in Chaco Canyon. The data presented in this and other studies (e.g., Toll, 1991; English et al., 2001) suggests that the Chaco Corridor may have been the region over which the elites in Chaco Canyon exhibited the greatest amount of socio-political control/cooperation prior to A.D. 1130. In some sense, the Rio Chaco from the Great Bend to Chaco Canyon may have acted as the principal supply route for timber, pottery, maize, and other materials that were exported to Chaco.

\section{References}

Adams, D.K., Comrie, A.C., 1997. The North American monsoon. Bulletin of the American Meteorology Society 78, 2197-2213.

Adams, K.R., Meegan, C.M., Ortman, S.G., Howell, R.E., Werth, L.C., Muenchrath, D.A., O'Neill, M.K., Gardner, C.A.C., 2006. MAIS (Maize of American Indigenous Societies) Southwest: Ear Descriptions and Traits that Distinguish 27 Morphologically Distinct Groups of 123 Historic USDA MAIZE (Zea mays L. spp. Mays) Accessions and Data Relevant to Archaeological Subsistence Models. http://spectre.nmsu.edu (projects and results, collaborative MAIS Experiment).

Benson, L.V., 2010. Who provided maize to Chaco Canyon after the mid- $12^{\text {th }}$ century drought? Journal of Archaeological Science 37, 621-629.

Benson, L.V., 2011a. Factors controlling pre-Columbian and early historic maize productivity in the American Southwest, part 1: the Southern Colorado Plateau and Rio Grande regions. Journal of Archaeological Method and Theory 18, 1-60.

Benson, L.V., 2011b. Factors controlling pre-Columbian and early historic maize productivity in the American Southwest, part 2: the Chaco Halo, Mesa Verde, Pajarito Plateau, and Zuni archaeological regions. Journal of Archaeological Method and Theory 18, 61-110.

Benson, L.V., Berry, M.S., 2009. Climate change and cultural response in the prehistoric American Southwest. Kiva 75, 89-119.

Benson, L.V., Petersen, K., Stein, J., 2007. Anasazi (pre-Columbian Native American) migrations during the middle-12th and late-13th centuries-were they drought induced? In: Diaz, H. (Ed.), Climate and Cultural History in the Americas Climatic Change, vol. 83, pp. 187-213.

Benson, L.V., Stein, J.R., Taylor, H.E., 2009. Possible sources of archaeological maize found in Chaco Canyon and Aztec Ruin, New Mexico. Journal of Archaeological Science 36, 387-407.

Benson, L.V., Hattori, E.M., Taylor, H.E., Poulson, S.R., Jolie, E.A., 2006a. Isotope sourcing of prehistoric willow and tule textiles recovered from western Great Basin rockshelters and caves - proof of concept. Journal of Archaeological Science 33, 1588-1599.

Benson, L.V., Stein, J.R., Taylor, H.E., Friedman, R., Windes, T.C., 2006b. The agricultural productivity of Chaco Canyon and the source(s) of pre-Hispanic maize found in Pueblo Bonito. In: Staller, J.E., Tykot, R.H., Benz, B.F. (Eds.), Histories of Maize. Academic Press, New York, pp. 289-314.

Benson, L.V., Taylor, H.E., Plowman, T.I., Roth, D.A., Antweiler, R.C., 2010. The cleaning of burned and contaminated archaeological maize prior to ${ }^{87} \mathrm{Sr} /{ }^{86} \mathrm{Sr}$ analysis. Journal of Archaeological Science 37, 84-91.

Benson, L.V., Taylor, H.E., Peterson, K.A., Shattuck, B.D., Ramotnik, C.A., Stein, J.R., 2008. Development and evaluation of geochemical methods for the sourcing of archaeological maize. Journal of Archaeological Science 35, 912-921.

Benson, L.V., Cordell, L.S., Vincent, K.R., Taylor, H.E., Stein, J.R., Farmer, G.L., Futa, K., 2003. Ancient maize from Chacon great houses: where was it grown? Proceedings of the National Academy of Sciences 22, 13111-13115.

Berry, M.S., Benson, L.V., 2010. Tree-ring dates and demographic change in the Southern Colorado Plateau and Rio Grande regions. In: Kohler, T., Varien, M., Wright, A. (Eds.), Leaving Mesa Verde: Peril and Change in the Thirteenthcentury Southwest. University of Arizona Press, Tucson, pp. 53-74.

Bernardini, W., 1999. Reassessing the scale of social action at Pueblo Bonito, Chaco Canyon, New Mexico. Kiva 64, 447-470.

Biermann, G.J., 1996. Handbook of Pulping and Cleaning. Academic Press, New York.

Brennan, M.A., Shelley, M.L., 1999. A model of the uptake, translocation, and accumulation of lead $(\mathrm{Pb})$ by maize for the purpose of phytoextraction. Ecological Engineering 12, 271-297.

Brown, G.M., Windes, T.C., McKenna, P.J., 2008. Animas anamnesis: Aztec ruins or Anasazi capital? In: Reed, P.F. (Ed.), Chaco's northern prodigies. The University of Utah Press, Salt Lake City, pp. 231-250.

Bunker, A., 2001. Peromyscus Maniculatus (Online). Animal Diversity Web. http:// animaldiversity.ummz.umich.edu/site/accounts/information/Peromyscus_ maniculatus.html.

Cameron, C.M., 2001. Pink chert, projectile points, and the Chacoan regional system. American Antiquity 66, 79-101.

Cordell, L.S., Toll, H.W., Toll, M.S., Windes, T.C., 2008. Archaeological corn from Pueblo Bonito, Chaco Canyon, New Mexico: dates, contexts, sources. American Antiquity $73,491-511$. 
Dean, J.S., van West, C.R., 2002. Environment-behavior relationships in southwestern Colorado. In: Varien, M.D., Wilshusen, R.H. (Eds.), Seeking the Center Place. The University of Utah Press, Salt Lake City, pp. 81-99.

Doyel, D.E., Breternitz, C.D., Marshall, M.P., 1984. Chacon community structures: Bis sa'ani pueblo and the Chaco Halo. In: Judge, W.J., Schelberg, J.D. (Eds.), Recent research on Chaco prehistory. Reports of the Chaco Center No. 8. Division of Cultural Research, National Park Service, Albuquerque, pp. 37-54.

English, N.B., Betancourt, J.L., Dean, J.S., Quade, J., 2001. Strontium isotopes reveal distant sources of architectural timber in Chaco Canyon, New Mexico. Proceedings of the National Academy of Sciences 98, 11891-11896.

Faegri, K., Iverson, J., 1975. Textbook of Pollen Analysis. Hafner Press, New York.

Fowler, A.P., Stein, J.R., 1992. In: Doyel, D.E.(Ed.), The Anasazi great house in space, time, and paradigm, Anasazi regional organization and the Chaco system. The Maxwell Museum of Anthropology, University of New Mexico, Albuquerque, pp. 101-122.

Friedman, R.A., Stein, J.R., Blackhorse Jr., T., 2003. A study of a pre-Columbian irrigation system at Newcomb, New Mexico. Journal of GIS in Archaeology 1,1-10.

Hovezak, M.J., 1993. Annual Report on Environmental Archaeology Program Research, 1992 Field Season. Crow Canyon Archaeological Research Center, Cortez, Colorado.

Huntington, E., 1914. The Climatic Factor as Illustrated in Arid America. Carnegie Institution of America Publication 192, Carnegie Institute, Washington D.C.

Judge, W.J., 1979. The development of a complex cultural ecosystem in the Chaco Basin, New Mexico. In: Linn, R.L. (Ed.), Proceedings of the First Conference on Scientific Research in the National Parks 2. U.S. Government Printing Office, Washington, D.C.

Judge, W.J., 1989. Chaco Canyon-San Juan Basin. In: Cordell, L.S., Gumerman, G.J. (Eds.), Dynamics of Southwest Prehistory. Smithsonian Institution, Washington, D.C, pp. 209-261.

Judge, W.J., Cordell, L.S., 2006. Society and polity. In: Lekson, S.H. (Ed.), The Archaeology of Chaco Canyon. School of American Research Press, Santa Fe, pp. 189-210.

Kantner, J., 2003. Rethinking Chaco as a system. Kiva 69, 207-227.

Kintigh, K.W., Glowacki, D.M., Huntley, D.L., 2004. Long-term settlement history and the emergence of towns in the Zuni area. American Antiquity 69, 432-456.
Lehrfeld, J., 1996. Conversion of agricultural residues into cation exchange materials. Journal of Applied Polymer Science 61, 2099-2105.

Lekson, S.H., 1986. Great Pueblo Architecture of Chaco Canyon New Mexico. University of New Mexico Press Albuquerque.

Marshall, M.P., Stein, J.R., Loose, R.W., Novotny, J.E., 1979. Anasazi communities of the San Juan Basin. Public Service Company of New Mexico and the New Mexico Historic Preservation Bureau, Albuquerque.

Morris, E.H., 1921. The house of the great kiva at Aztec Ruin. American Museum of Natural History Anthropological Papers 26, 109-138.

Muenchrath, D.A., 1995. Productivity, Morphology, Phenology and Physiology of Desert-adapted Native American Maize (Zea mays L.) Cultivar. PhD dissertation, University of Iowa, Ames.

Nassar, M.M., 2006. Adsorption of $\mathrm{Fe}^{+3}$ and $\mathrm{Mn}^{+2}$ from ground water onto maize cobs using batch adsorber and fixed bed column. Separation Science and Technology 41, 943-959.

Sebastian, L., 2006. The Chaco Synthesis. In: Lekson, S.H. (Ed.), The Archaeology of Chaco Canyon. School of American Research Press., Santa Fe, pp. 393-422.

Shaw, R.H., 1988. Climate requirement. In: Sprague, G.F., Dudley, J.W. (Eds.), Corn and Corn Improvement, third ed. American Society of Agronomy, Madison, pp. 609-638.

Stuart, J.W., 1990. Maize use by rural Mesoamerican households. Human Organization 49, 135-139.

Toll, H.W., 1985. Pottery, Production, Public Architecture, and the Chaco Anasazi System. PhD dissertation, University of Colorado, Boulder.

Toll, H.W., 1991. Material distributions and exchange in the Chaco system. In: Crown, P.L., Judge, W.J. (Eds.), Chaco and Hohokam. School of American Research Press., Santa Fe, pp. 77-107.

Windes, T.C., 1984. A new look at population in Chaco Canyon. In: Judge, W.J., Schelberg, J.D. (Eds.), Recent Research on Chaco Prehistory. National Park Service Reports of the Chaco Center no. 8, pp. 75-87. Albuquerque.

Windes, T.C., 2003. This old house, construction and abandonment at Pueblo Bonito. In: Neitzel, J.E. (Ed.), Pueblo Bonito: Center of the Chacoan world. Smithsonian Books, Washington, D.C, pp. 14-32. 